This is a preprint that has no-yet undergone peer-review. Please note that subsequent versions of this manuscript may have different content. We share this preprint to openly share our ongoing work and to generate community discussion; we warmly welcome comments or feedback via email (c.jackson@imperial.ac.uk). 


\section{Tectono-stratigraphic development of a salt-influenced rift margin; Halten Terrace, offshore Mid-Norway}

Gavin M. Elliott ${ }^{* 1}$, Christopher A-L. Jackson ${ }^{1}$, Robert L. Gawthorpe ${ }^{2}$, Paul Wilson ${ }^{3,6}$,

Ian R. Sharp ${ }^{4} \&$ Lisa Michelsen ${ }^{5}$

${ }^{1}$ Basin Research Group (BRG), Department of Earth Science \& Engineering, Imperial College London, London, UK

${ }^{2}$ Department of Earth Sciences, University of Bergen, Norway

${ }^{3}$ Basin Studies \& Petroleum Geoscience, SEAES, University of Manchester, Manchester UK

${ }^{4}$ Equinor Research Centre, Sandsliveien 90, Bergen, Norway

${ }^{5}$ Equinor ASA, MøInholtet 42, Harstad, Norway

${ }^{6}$ Now at: Schlumberger Oilfield UK PLC, Schlumberger House, Gatwick, UK *Corresponding Author Email: gavinmelliott@gmail.com

\section{Abstract}

In salt-influenced rift basins the presence of a pre-rift salt layer will control the tectono-stratigraphic evolution of the rift due to the decoupling of the sub- and suprasalt faults leading to temporal and spatial variations in structural style. Lateral variations in rift flank structure will control the dispersal and volumes of sediment deposited in rifts and along rifted margins, which in turn impacts facies distributions within syn-rift stratigraphic successions. We here use 3D seismic reflection and borehole data to study the tectono-stratigraphic development of the Halten Terrace, offshore Mid-Norway, a salt-influenced rifted margin formed during Middle to Late Jurassic extension. On the eastern basin margin the rift structural style passes southwards from an unbreached extensional growth fold dissected by numerous horst and graben (Bremstein Fault Complex), into a single, through-going normal fault (Vingleia Fault Complex). This southwards change in structural style is likely related to the pinch-out of or a change of lithology (and thus rheology) within a prerift (Triassic) evaporite layer, which was thick and/or mobile enough in the north to 
decouple basement- and cover-involved extension, and to permit forced folding. The salt-influenced Bremstein Fault Complex underwent limited footwall uplift, with minor erosion of relatively small horsts supplying only limited volumes of sediment to the main downdip depocentre. In contrast, the more directly basement-coupled Vingleia Fault Complex experienced extensive footwall erosion, in addition to collapse of its footwall due to salt-detached gravity gliding. Our results show that where throughgoing normal faults develop along the rift flanks, the presence of a pre-rift salt layer will suppress footwall topographic expression. The pre-rift salt layer will facilitate footwall collapse and limit the sediment supply to the basins downdip. In addition, our result shows that variable topography along the rift flanks facilitated small, localised, intra-rift flank accommodation space limiting sediment supply deeper into the rift basin.

\section{Introduction}

Several tectono-stratigraphic models have been produced for rift systems developed in predominantly brittle basement (pre-rift) rocks (Prosser 1993; Gawthorpe \& Leeder 2000; Ravnås et al., 2000). These models predict that rift systems will evolve from an initial stage characterised by numerous, small, isolated normal faults defining relatively subdued topography (rift-initiation), to a stage where extension is focussed on fewer, larger faults systems bounding large half-graben depocentres and prominent footwall topographic highs (rift-climax) (Prosser 1993; Gawthorpe \& Leeder 2000; Ravnås et al., 2000). This so-called 'strain localisation' controls the interplay between structurally produced accommodation, sediment source areas, and sediment transport pathways, which together control the syn-rift stratigraphic 
evolution of a rift system and its constituent basins (Gupta et al., 1998; Gawthorpe \& Leeder 2000). For example, during the rift initiation low fault slip rates result in only limited accommodation and because sediment accumulation rates may exceed subsidence rates and the rate of accommodation development, basins may be overfilled at this time. In contrast, during the rift climax, fault slip rates, basin subsidence rates, and the rate of accommodation development may be less than or equal to the sediment accumulation rate, resulting in under-filled basins (Gawthorpe et al 1994; Gawthorpe \& Leeder 2000). During the rift-climax, footwalls may also become major intra-rift sediment sources, with margin-sourced material being trapped in more proximal depocentres (Underhill et al., 1997; McLeod \& Underhill 1999; Welbon et al., 2007; Bilal et al., 2018).

In rifts containing salt within the pre-rift stratigraphy, these existing tectonostratigraphic rift models may not be applicable because the flow of these ductile bodies may modify or fully overprint the uplift and subsidence patterns related to normal faulting and associated folding (Withjack et al., 1990; Richardson et al., 2005; Marsh et al., 2010; Duffy et al., 2012; Rowan 2014; Jackson \& Lewis 2016; Tavani \& Granado 2015; Tavani et al., 2018; Jackson et al., 2019). Pre-rift salt may act as an intra-stratal detachment, partially or fully decoupling thick- (basement-involved) and thin-skinned (cover-restricted) structures accommodating extension (Withjack et al., 1990; Richardson et al., 2005; Marsh et al., 2010; Rowan 2014). Fault-propagation folding, which is related to the vertical propagation of basement-involved structures through the evaporite, may also be more common in salt-influenced rifts (Corfield \& Sharp 2000).

The geomorphology and tectono-stratigraphic evolution of salt-influenced rifts may therefore differ to that of salt-free rifts. Rowan (2014) reviewed the role of evaporates 
and salt tectonics have on continental margin development but was largely restricted to seismic examples where only part of the sequence has been drilled reducing the certainty on the age of the older stratigraphy and timing of events in the rift evolution. The Late Jurassic of the Halten Terrace provides an unique opportunity to be able to understand the role of a pre-rift salt layer has upon the tectono-stratigraphic evolution of rift basins thanks largely to the moderate burial depths which permit good quality seismic imaging of the stratigraphic section from Paleozoic to recent. In addition, the Halten Terrace has a large number of wells with biostratigraphic data which allowed the development of a basin-wide temporal framework within which the timing of erosion and sediment supply within an evolving rift basin could be constraining. Rift basins models such as Gawthorpe \& Leeder (2000) provide a good insight into the spatial variation of the structural and stratigraphic evolution of a rift basin but they lack a temporal framework within with to understand these processes.

In this paper we couple structural and seismic-stratigraphic mapping from 3D seismic reflection and borehole data along the Halten Terrace, offshore mid-Norway to determine the role that relatively thin $(<500 \mathrm{~m})$, pre-rift salt had on the Middle to Late Jurassic ( 27 Myr) syn-rift tectono-stratigraphic development of a rifted margin. Integration of sub-crop mapping along the major border faults combined with seismic stratigraphy of the hangingwall depocentres allowed us to demonstrate the impact of the pre-rift salt had on the structural configuration of the rift flanks which in turn determined the volume and facies of the sediment delivered to the depocentres.

\section{Geological setting}

\subsection{Structural framework of the Halten Terrace}


101 The Halten Terrace is a c. $80 \mathrm{~km}$ wide by c. $130 \mathrm{~km}$ long, normal fault-bounded

102

103

104

105

106

107

108

109

110

111

112

113

114

115

116

117

118

119

120

121

122

structural platform that is located between $64^{\circ}$ and $65^{\circ} 30^{\prime} \mathrm{N}$ on the mid-Norwegian continental shelf (Figure 1) (Blystad et al., 1995; Zastrozhnov et al., 2020). The area has been subject to a complex, long-lived, multi-phase extensional history, from the Devonian through to the opening of the NE Atlantic in the Cenozoic; the Late Jurassic-Early Cretaceous extensional phase forms the focus of this paper (e.g. Bukovics et al., 1984; Blystad et al., 1995; Doré et al., 1997; 1999; Roberts et al., 1999; Brekke, 2000; Faleide et al., 2008).

The structural evolution of the Halten Terrace results, in part, from the interaction between Late Jurassic-Early Cretaceous rift-related normal faults and a thin $(<500$ m) pre-rift, Triassic, evaporite-dominated layer (Jacobsen and van Veen, 1984; Wilson et al., 2015). This unit served to variably decouple rift-related deformation in sub- and supra-salt strata, resulting in the development of extensional fault propagation folds, and basement-involved and basement-detached normal faults (Figure 1c) (Withjack et al., 1989; Pascoe et al., 1999; Corfield and Sharp, 2000; Dooley et al., 2003; Richardson et al., 2005; Marsh et al., 2010; Wilson et al., 2013; 2015; Tavani \& Granado 2015; Tavani et al., 2018;). In contrast to other saltinfluenced rift basins such as Northern Northern Sea (Stewart et al., 1997; Richardson et al., 2005; Kane et al., 2010; Rowan 2014; Jackon et al., 2019) the Halten Terrace salt, despite its relatively thin nature and lack of diapiric behaviour exerts a strong influence on the tectono-stratigrahic evolution of the syn-rift. 
We focus on the southern and eastern margins of the Halten Terrace. Here, the Ntrending Bremstein and NE-trending Vingleia fault complexes separate the Trøndelag Platform and Frøya High from the Gimsan Basin (Figure 1) (Wilson et al., 2015). The Vingleia Fault Complex merges to the south with the N-S-striking, Klakk Fault Complex and the Sklinna Ridge, which together define the western limit of the rhombic, Halten Terrace (Figure 1 \& 2) (Blystad et al., 1995). Internally, the Halten Terrace contains numerous Triassic-to-Jurassic, tilted normal fault blocks and subbasins with the elliptical, $2200 \mathrm{~km}^{2}$, N-trending Gimsan Basin representing one of the largest syn-rift depocentres on the Halten Terrace (Figure 1 \& 2) (Blystad et al., 1995).

The Bremstein Fault Complex is a thin-skinned, cover-restricted fault system that detaches downwards into the Triassic salt (Wilson et al., 2013) (Figure 2). In contrast the Vingleia Fault Complex cross-cuts the salt and is basement-involved, defining the northeastern flank of the Frøya High (Figure 1). The Frøya High is a N-trending, normal fault-bound, granite-cored horst that is $\sim 120 \mathrm{~km}$ long and up to $40 \mathrm{~km}$ wide (Blystad et al., 1995; Slagstad et al., 2011). The along strike variation in structural style from a zone of diffuse faulting and an unbreached fault-propagation fold (i.e. the Bremstein Fault Complex) to a narrow zone of focused deformation (Vingleia Fault Complex) is key to the syn-rift tectono-stratigraphic evolution of the eastern margin of the Halten Terrace (Wilson et al., 2013; 2015).

\subsection{Stratigraphic framework of the Halten Terrace}


The Early Jurassic to early Middle Jurassic stratigraphy comprises paralic-toshallow-marine, sandstone- (Garn \& lle formations) and mudstone-rich (Not \& Ror formations) units that record deposition during the late pre-rift to early syn-rift period (rift initiation; Figure 3) (Gjelberg et al., 1987; Dalland et al., 1988; Swiecicki et al., 1998; Martinius et al., 2001; 2005; Messina et al., 2014). The late syn-rift period occurred during the late Middle Jurassic to Late Jurassic, and was characterised by accelerated rates of extension and normal fault-controlled subsidence. Increasing rates of accommodation generation resulted in drowning of the Halten Terrace and deposition of an open marine, mudstone-dominated succession (Melke and Spekk formations) (rift climax; Figure 2) (Dalland et al., 1988; Swiecicki et al., 1998). However, some of the largest basement-cored structural highs remained sub-aerially exposed during the Late Jurassic and were flanked by relatively coarse-grained, clastic depositional systems (e.g. Rogn Formation) (Dalland et al., 1988; van der Zwan, 1990; Provan, 1992; Chiarella et al., 2020). The Rogn Formation, which is composed of highly bioturbated, fine-to-medium grained sandstones in the Draugen Field, is located on the footwall of the Vingleia Fault Complex (Figure 1). Traditionally, the Rogn Formation has been interpreted as a shallow marine 'detached' bar system, deposited tens of kilometres from the contemporaneous shoreline (van der Zwan, 1990; Provan, 1992). However, Chiarella et al., (2020) propose that the Rogn Formation is a tidally influenced sand body deposited on a shallow shelf.

Coarse clastic units broadly age-equivalent to the Rogn Formation (Oxfordian to Kimmeridgian) are drilled in the hangingwall of the Vingleia Fault Complex where it defines the edge of the basement-cored Frøya High (Elliott et al., 2017) (Figure 1). Here, the Fenja Discovery is hosted in the Bajocian to Oxfordian Melke Formation 
172 (NPD Factpages 2020). Despite new data being provided by these relatively recent boreholes, the lithology, facies, and tectono-stratigraphic context of the Melke and Spekk formations are poorly documented and form the focus of the current study.

\section{Dataset and Methodology}

Stratigraphic and structural mapping was mainly conducted on four time-migrated, 3D seismic reflection datasets that cover c. $3200 \mathrm{~km}^{2}$ of the southern Halten Terrace (Figure 1). These 3D volumes were tied to 2D seismic reflection profiles to provide regional, basin-scale context to the stratigraphic and structural observations and interpretations (Figure 1). The 3D seismic volumes have an inline and crossline spacing of $12.5 \mathrm{~m}$. The vertical (depth) axis is measured in milliseconds two-way time (ms TWT) and the seismic data have a vertical record length of $5500 \mathrm{~ms}$ TWT. Frequency analysis of these seismic data indicates that the vertical resolution within the interval of interest is $20-30 \mathrm{~m}$ (Figure 3 ). The seismic data were tied to exploration wells using synthetic seismograms, allowing stratigraphic ages (using the framework of Dalland et al., 1988) to be assigned to mappable seismic reflections and permitting a direct lithological calibration of the syn-rift seismic facies (Figure 3). Although the seismic reflection events can be mapped over the basin to define seismic-stratigraphic packages, these packages contain several lithostratigraphic units within them representing lateral facies changes (Figure 3). Isochron (thickness) maps were generated to investigate spatial variations in stratigraphic thickness away from areas of well control; thickness variations were used to identify syn-depositional structures and depositional elements. We also mapped subcrop patterns below and onlap patterns above, the major unconformities in the footwall of the Vingleia Fault 
Complex to examine the timing and depth of erosion, and the potential provenance of sediments contained within the adjacent depocentres.

We used 17 key wells containing a full suite of petrophysical well logs (Table 1 \& Figure 1b). Twelve of the wells were located along the footwalls of the Bremstein and Vingleia fault complexes with the remainder in the Gimsan Basin to the west (Figure 1b). Very little Upper Jurassic core has been cut in the study area, thus the lithology and facies of units has been inferred from well cuttings reports, linked to petrophysical well-log characteristics and the overall tectono-stratigraphic context of individual wells and units (e.g. structural and stratigraphic position within the syn-rift succession). Thirteen of the wells had proprietary biostratigraphic data which allowed the ages of key stratal surfaces to be constrained and facilitated the construction of chronostratigraphic correlation panels. Seismic profiles that passed between wells were used to provide a tectono-sedimentary context to the stratigraphic data (e.g. stratal thickening across syn-depositional normal faults) in these panels and to quality control the correlation itself.

\section{Rift flank}

\subsection{Rift flank structural configuration}

The Bremstein Fault Complex is characterised by westward-dipping strata that define a $15 \mathrm{~km}$ wide monocline limb that has been dissected by a series of supra-salt thin-skinned cover restricted normal faults (Figure 4a) (Withjack et al.,1989; 1990; Dooley et al., 2003, Wilson et al., 2013; 2015). The supra-salt faults strike N-S, are 
up to $20 \mathrm{~km}$ long and have up to $650 \mathrm{~ms}$ TWT throw, and are both antithetic and synthetic to the sub-salt master fault (Figures 4a). The Bremstein Fault Complex varies geometrically along its length; in the north of the study area, it is bound to the west by a basement involved normal fault with a strongly listric normal fault in its footwall at Upper Jurassic levels (Figure 1c). Further south, it is characterised at Upper Jurassic levels by a fault-parallel, faulted monocline developed above major sub-salt faults (Figure 4a).

The transition from the Bremstein to Vingleia Fault Complex is defined not only by a southward change in strike from N-S to NE-SW, but also an overall structural style from numerous supra-salt thin-skinned cover restricted faults overlying a single basement-involved normal fault to a fault complex characterised by distributed, thickbasement involved faults (Wilson et al., 2015). The change in strike is most likely due to the intra-basement structures controlling the location of the Jurassic to Earliest Cretaceous rift faults (Wilson et al., 2015).

The Vingleia Fault Complex is characterised by basement-involved normal fault systems that offset the Triassic evaporite package by up to 2 sec. TWT (Figure 4b). The hangingwall of the Vingleia Fault Complex is defined by a $30 \mathrm{~km}$ long and 5-10 $\mathrm{km}$ wide, fault-parallel syncline, whereas the footwall is characterised by several gently rotated fault blocks (Figure $4 \mathrm{~b}$ ). The footwall fault blocks are up to $2 \mathrm{~km}$ wide, bounded by broadly NE-SW striking normal faults that have up to $150 \mathrm{~ms}$ TWT of throw and are up to $5 \mathrm{~km}$ long (Figure 9). These faults are downthrown to progressively deeper structural levels towards the NW (i.e. into the hangingwall) and in section they detach downwards into the Triassic salt layer, which dips and deepens westwards (Figure 4b). The majority of the faults downthrow to the NW, but a distinct NE-SW striking horst block, bounded on its south-eastern side by a SE- 
dipping normal fault, defines the eastern limit of tilting and faulting in the footwall of the Vingleia Fault Complex. East of this horst the footwall is relatively undeformed, forming a gently eastward-dipping structural terrace (Figure 9).

\subsection{Rift flank erosion}

The Triassic and Jurassic stratigraphy along the westernmost edge of the Trøndelag Platform are of relatively uniform thickness, although the BCU progressively cuts down such that Lower Cretaceous strata directly overlie Early Jurassic strata in the south (Figure 5). Variations in the magnitude of erosion along the footwall of the Bremstein and Vingleia Fault Complexes are indicated by an uppermost Triassic-toUpper Jurassic isochron map (Figure 5). The related succession in the footwall of the Bremstein Fault Complex displays little variation in thickness ( 1300 ms TWT thick), although it thins towards the Bremstein Fault Complex over a lateral distance of 10 $\mathrm{km}$. This thinning is related to the gradual downcutting of the BCU towards the fault complex, with localised deeper erosion found in the immediate footwall of the easternmost fault in the Bremstein Fault Complex (see also Elliott et al., 2012). In contrast, the equivalent succession in the footwall of the Vingleia Fault Complex is more variable in thickness (1200 - 0 ms TWT), ultimately thinning towards the footwall crest of the fault complex, where it is locally absent or below seismic resolution. The boundary between these two styles of erosion is co-incident with a NE-SW-striking basement-involved normal fault that breaches the salt and BCU, and tips out within the lowermost Cretaceous interval (Figure 5). 


\subsubsection{Bremstein Fault Complex}

The style of erosion in the footwall of the Bremstein Fault Complex varies along strike. First, there is a region of very localised footwall erosion extends up to $3 \mathrm{~km}$ into the footwall of the easternmost fault within the complex (Figure 6a). Erosion patterns that resemble drainage catchments have been described in detail by Elliott et al., (2012) are up to $7 \mathrm{~km}^{2}$ in area and display erosional relief of up to $150 \mathrm{~m}$ (Figure 6a).

In contrast to the relatively organised style of degradation described by Elliott et al., (2012), which is only locally developed, the majority of fault blocks that comprise the Bremstein Fault Complex have undergone gravitational collapse. In one example, footwall collapse has occurred along listric detachment surfaces which detach into the mudstone-dominated Ror Formation (Figure 7). A consequence of the footwall collapse is that fault block crests are characterised by semi-circular scarps that have resulted from the downslope translation and rotation of collapse blocks up to $1.5 \mathrm{~km}$ wide and $750 \mathrm{~m}$ long (Figure 7).

The complex and varied topography that developed along the length of the Bremstein Fault Complex during the Middle to Late Jurassic provided localised depocentres within the normal fault complex itself (Figure 8). The sediment contained within these depocentres is likely to have been sourced locally from the erosion and degradation of fault block crests from within the Bremstein Fault Complex, rather than from locations further west. Two key observations suggest erosion of these fault blocks and related syn-rift deposition occurred in the Oxfordian. First, well 6407/6-7S, which is located in the hangingwall of the easternmost fault and downdip of the erosional catchments, cored an $18 \mathrm{~m}$ thick, Oxfordian turbidite 
succession interbedded with an otherwise mudstone-prone succession (Spekk Formation) (Figure 8a). Second, well 6407/6-4, which is located within the Bremstein Fault Complex, penetrated a 100 m thick, fine-grained siltstone syn-rift succession (Melke Formation) in unconformable contact with the underlying Garn Formation across a Middle Oxfordian erosional surface (Figure 8b).

\subsection{Vingleia Fault Complex}

Seismic data indicate that erosion levels along the footwall of the Vingleia Fault Complex becomes progressively deeper overall towards the crest of the footwall and increases southwards towards the Frøya High (Figure 5). In contrast to the Bremstein Fault Complex, the footwall of the Vingleia Fault Complex is not degraded by relatively organised, locally developed, focused incision, or more disorganised and widespread landsliding. Instead, its footwall is characterised by a gently eastward-dipping peneplain-like surface and a series of westward-dipping, erosionally capped terraces created by the top surfaces of the rotated fault blocks (Figure 9).

Seismic mapping in the footwall of the Vingleia Fault Complex reveals that the Upper Jurassic succession is relatively thin (typically $<100$ ms TWT; Figure 9), meaning the erosional history and style in this location cannot be resolved by using seismic data alone. However, by using biostratigraphically-constrained well correlation panels, we can assess the variability in erosion levels in the Vingleia Fault Complex footwall. These stratigraphic data reveal that three major erosional unconformities are developed in the Middle to Upper Jurassic syn-rift succession in the footwall of the Vingleia Fault Complex (Figure $9 \& 10$ ). The lowermost unconformity, which is early 
Callovian and which defines the top of the Garn Formation, is mapped across the entire footwall (including to the E of the NE-SW-striking horst) suggesting it was not simply formed due to relatively local, fault-driven uplift. The early Callovian unconformity dips gently to the east and is progressively onlapped by Middle to Late Callovian strata (the Melke Formation to the north and Spekk Formation to the south; Figures 9 and 10).

A younger, early Oxfordian unconformity is developed above and locally merges with the early Callovian unconformity on the flanks of the NE-SW-striking horst (labelled A in Figure 9), where it forms part of a composite, erosional unconformity capping the Vingleia Fault Complex (Figure $9 \& 10$ ). An important observation is that the composite unconformity can be traced within the rotated fault blocks at different structural elevations; combined with the fact that the units above and below the unconformity in $6407 / 8-4 \mathrm{~S}$ are of similar age to that observed in $6407 / 9-4$, these observations suggest that the footwall was a single structure when the unconformity formed during the early Oxfordian, and that it was subsequently dissected by normal faults (Figure 9). The prominent NE-trending horst (A in Figure 9) has been eroded, removing the Melke and Garn formations, resulting in the Spekk Formation (Tithonian) sitting directly on the Not Formation (Bajocian) in well 6407/9-9 (Figure 9). East of the horst, Kimmeridgian-to-Early Tithonian shallow marine shoreface sandstone of the Rogn Formation were deposited directly onto the Early Oxfordian Unconformity (Figures 9 \& 10). Late Tithonian-to-Berriasian aged Spekk Formation can be traced across the footwall of the Vingleia Fault Complex, where it is overlain by Early Cretaceous strata across the Base Cretaceous Unconformity, the third and final unconformity identified along Vingleia Fault Complex (Figures 9 and 10). 
The Gimsan Basin defines the hangingwall of the Bremstein and Vingleia Fault Complexes (Figures $2 \& 4$ ). The basin comprises three sub-basins, with a NEtrending structural high separating two of them (Figure 11); the largest and deepest depocentre is located in the SE, in the immediate hangingwall of the Vingleia Fault Complex where it is defined by a single through-going fault (Figure $5 \& 11$ ). A NEtrending structural high, which overlies the footwall of an underlying, basementrestricted, blind normal fault that splays off from the Bremstein Fault Complex separates the two northern sub-basins of the Gimsan Basin (Figure 11).

The Middle to Late Jurassic succession in the Gimsan Basin is characterised by moderate- to low-amplitude, semi-continuous reflection events. We map two main seismic units within the Gimsan Basin; well data indicate these correspond to the Melke and Spekk formations (Figure 11). The base of the Melke Formation is represented by a prominent reflection event, although the absolute age of this event is poorly constrained due to a paucity of well penetrations through the base of the unit. However, regional chronostratigraphy data suggest the base of the Melke Formation in the Gimsan Basin is Bajocian to Early Bathonian (Dalland et al., 1988) (Figure 3). The Melke Formation is up to 400 ms TWT thick in the largest depocentre and up to $150 \mathrm{~ms}$ TWT in the smaller depocentres either side of the NE-trending, intra-basin high (Figure 11). Five wells have penetrated part of the Melke Formation; three of these are located around the margins of Gimsan Basin and two are located close to the intra-basin high (Figure 12). Cuttings and well-log data (i.e. GR 50 -100 API) suggest the formation is dominated by claystone and thin, very-fine to fine- 
grained sandstone and carbonates in the deepest part of the basin (e.g. 6407/8-1 and 6407/5-1; Figure 12). Towards the basin flanks the formation thins; here, interbedded siltstones and carbonates are the dominant lithologies (e.g. 6407/2-1, $6407 / 7-8 \& 6407 / 4-1 ;$ Figure 12). In the immediate hangingwall of the Vingleia Fault Complex the Melke Formation is characterised by a series of higher-amplitude, mounded, convex-up packages of seismic reflections that downlap the Top Garn reflection (Figure 13). These mounded bodies are up to $200 \mathrm{~ms}$ TWT thick, extend up to $4 \mathrm{~km}$ away from fault, and can be traced for $10 \mathrm{~km}$ parallel to the fault (Figure 13). In detail, individual mounded bodies exhibit a compensational stacking pattern, with stratigraphically younger mounds onlapping underlying mounds and with their axes offset from the crests of the older mounds (Figure 13b). South of the study area, similar age sandbodies form the reservoir in the Fenja Discovery, which is also situated in the hangingwall of the Vingleia Fault Complex but in a different sub-basin (NPD Factpages Accessed August 2020).

The Spekk Formation is thicker than the Melke Formation (up to $700 \mathrm{~ms}$ TWT) and is thickest in the south immediately adjacent to the Vingleia Fault Complex (Figure 11). The formation is dominated by claystone, as indicated by high values on gamma-ray logs (>150 API), but rare, thin sandstones and carbonates are locally developed (Figure 12). In cross-section the Spekk Formation is characterised by low-amplitude, semi-discontinuous reflection events; distinct geomorphological features, such as the mounded features in the underlying Melke Formation, are not observed (Figure 14a). More coherent, moderate-amplitude reflections are locally developed; a windowed RMS amplitude extraction around one such event reveals a series of curvilinear, high-amplitude lineations orientated parallel to the Bremstein Fault Complex (Figure 
14b). Similar features have been imaged by Løseth et al., (2011) in the overlying Lange Formation (Lower Cretaceous) and also in the vicinity of well 6407/5-1; these are interpreted as the seismic expression of a $50 \mathrm{~m}$ thick slide complex, sourced from the Bremstein Fault Complex and translated westwards into the Gimsan Basin. A RMS extraction taken from our dataset through the Lower Cretaceous slide complex described by Løseth et al. (2011) reveals a series of curvilinear lineations similar to those we have mapped and imaged in the Spekk Formation. Thus, by analogy, we interpret the curvilinear seismic facies in the Spekk Formation to represent a submarine slide complex (Figure 14c).

\section{Source-to-Sink Evolution of the Eastern Halten Terrace}

The tectono-stratigraphic evolution of the eastern Halten Terrace records the longterm ( $27 \mathrm{Ma})$ development of a salt-influenced rift basin. Our chronostratigraphic framework allows us to define five key tectono-stratigraphic phases, each of which is defined by a distinct structural style that is controlled by spatial variations in the thickness of a pre-rift salt layer. The five phases are also characterised by distinct, structurally controlled sediment dispersal patterns.

\subsection{Bathonian (167- $164 \mathrm{Ma})$}

Well and seismic data indicate that during the Bathonian, the study area was split into two different depositional regimes. The footwall of the Vingleia Fault Complex was characterised throughout by shallow marine conditions as recorded in the Garn Formation (Gjelberg et al., 1987; Messina et al., 2014)., whereas the Gimsan Basin 
and the footwall of the Bremstein Fault Complex were represented by slightly deeper-water, likely shelfal conditions of the Melke Formation (Figure 15a).

The nature or exact timing of the transgression from Garn to Melke Fm is unknown, but eastwards onlap of the Melke Formation onto the Garn Formation in the Gimsan Basin indicate that, during the Bathonian, the fault systems along the rifts eastern flank were active, but were expressed as an at-surface monocline (Figure 11) (i.e. extensional forced fold; Coleman et al., 2019). The mounded seismic facies imaged in the immediate hangingwall of the Vingleia Fault Complex are interpreted as submarine fans deposited on the western flank of the monocline limb (Figures 13 and 15a). The source of sediment for the submarine fans is unclear, but it may have been supplied by slope failure and reworking of Garn Formation sand from the western limb of the monocline (Figure 15a). Along the Bremstein Fault Complex, there is very little evidence for significant structural development at this time and a gentle monoclinal structure was likely present producing subtle bathymetric variations. Accumulation of the Melke Formation siltstones suggest that the footwall of the Bremstein Fault Complex was submarine during the Bathonian indicating an overall deepening of the basin northwards from the shallow marine footwall of the Vinglea Fault Complex (Figure 15a).

\subsection{Callovian (164 - $161 \mathrm{Ma})$}

Continued growth of the Vingleia Fault Complex resulted in breaching of the basin margin monocline and the formation of a single through-going structure. Formation of an at-surface, basement-involved normal fault drove uplift of the footwall of the Vingleia Fault Complex and the formation of a half-graben geometry (Figure 15b). 
Uplift caused sub-aerial exposure and erosion of the immediate crest of the footwall of Vingleia Fault Complex, which at this time likely represented an intra-rift island (Yielding 1990; Roberts \& Yielding 1991; Bell et al., 2014; Roberts et al., 2019). Some of the sediment derived from erosion of the Vingleia Fault Complex footwall will have been transported eastwards onto the hangingwall dipslope, likely deposited in shallow marine-to-shefal environments fringing the intra-rift island (Figure 15b). The lack of coarse-grained clastic deposits on the hangingwall dipslope implies that the Garn Formation was not exposed at the footwall crest at this time and that only relatively fine-grained, Bathonian deposits of the Melke Formation were exposed and reworked (Figure $9 \& 10$ ). We infer that the remaining sediment eroded from the intra-rift island was transported westwards into the immediate hangingwall of the Gimsan Basin, which at this time represented a major, deep-marine depocentre (Figure 5b). Like the hangingwall dipslope of the Vingleia Fault Complex, the Gimsan Basin accumulated a relatively fine-grained succession, again suggesting that the sand-rich Garn Formation was not exposed on the intra-rift island. In contrast to the footwall of the Vingleia Fault Complex, the footwall of Bremstein Fault Complex remained submarine throughout the Callovian, with siltstone (Melke Formation) accumulating in both its footwall and hangingwall (Figure 15b).

\subsection{Oxfordian (161 - $155 \mathrm{Ma})$}

The Early Oxfordian was characterised by siltstone accumulation in areas flanking the sub-aerially exposed Vingleia Fault Complex footwall, which at this time represented a region of non-deposition and/or erosion. A Middle Oxfordian erosional unconformity, recognised in wells from both the Vingleia and Bremstein Fault 
460

461

462

463

464

465

466

467

468

469

470

471

472

473

474

475

476

477

478

479

480

481

482

Complexes, indicates sub-aerial exposure and erosion along the former and a break in sedimentation along the latter (Figure 15c). The presence of Oxfordian turbidites "ponded" within relief associated with the Bremstein Fault Complex suggest that this structure was active during the Middle Oxfordian, an interpretation further supported by the presence of a possibly tectonically controlled unconformity in well 6407/6-4 (Figure 8). It is possible that these turbidites were derived from the drainage catchments imaged along the eastern edge of Bremstein Fault Complex (Figure 6) (see Elliott et al., 2012 for details).

We speculate that during the Oxfordian, the Vingleia Fault Complex formed a single, through-going normal fault, but that activity on the smaller faults associated with eventual collapse of its footwall may have produced some subtle relief. Erosion of this relief may have the yielded thin sandstones, such as those found within the middle to late Oxfordian of well 6407/6-7S (Figures 8 \& 15c). Similar gravity-flow emplaced deposits are found in similar hangingwall settings immediately downdip of a fault collapse complex in the Statfjord East field area, Northern North Sea (Welbon et al., 2007). The majority of the sediment delivered to hangingwall dipslope, will have been sourced from the erosion of the underlying Callovian and older shelfal siltstones, resulting in deposition of a relatively fine-grained Oxfordian succession (Melke Formation) (Figures $9 \& 10$ ). The Gimsan Basin continued to accumulate predominantly siltstone (Melke Formation) throughout the Oxfordian, suggesting that the majority of sediment was delivered eastwards from the Vingleia Fault Complex, implying that the regional tilt of the footwall controlled sediment pathways at that time. Along the Bremstein Fault Complex, the faulted monocline configuration produced numerous localised depocentres that trapped the sediment supplied from 
the erosion of the adjacent, intra-complex fault blocks, stopping it being delivered westwards to the deeper Gimsan Basin (Figure 15c).

\subsection{Kimmeridgian to Early Tithonian (155 - $147 \mathrm{Ma})$}

The Kimmeridgian to Early Tithonian represented a period of major clastic input onto the dipslope of the Vingleia Fault Complex, and associated deposition of a medium to coarse-grained, shallow marine succession (Rogn Formation) (Figure 15d). The Rogn Formation is interpreted to have been was derived from erosion of the sandstone-rich Garn Formation from the footwall crest of the Vingleia Fault Complex, forming either a detached shoreface system or tidal sand ridge (Figure 15d) ( van der Zwan, 1990; Provan, 1992; Chiarella et al., 2020). The sediment supplying this sandbody was sourced from relief associated with a minor phase of salt-detached, gravity-driven extension, faulting, and uplift along the NW-dipping footwall (Figure 15d). Footwall collapse may have been triggered by activity on the Vingleia Fault Complex, exposure of the evaporite detachment, and stretching and faulting of the overburden as it glided north-westwards towards the hangingwall (Figure 15d) (cf. 'rift-raft tectonics' of Penge et al., 1993). In addition, the progressive increase in erosion levels along the Vingleia Fault Complex footwall towards the Frøya High correspond to increased sediment accumulation in the SW corner of the Gimsan Basin (Figure 11b). It is unlikely that the Vingleia Fault Complex footwall supplied all of this sediment due to its limited size; it is more likely that sediment was channelled from the Frøya High into the Gimsan Basin, greatly enhancing sediment accumulation along with background hemipelagic and pelagic input (Figure 15d). 
507 The Bremstein Fault Complex is interpreted to have been in a submarine environment during the Kimmeridgian and Tithonian. A transition from the deposition of siltstone-dominated, shelfal sediments during the Kimmeridgian, to claystonedominated, deep-water deposits during the Early Tithonian, signifies a relative

511 increase in water depth. The Gimsan Basin continued to subside relative to the rift

512 flanks, with well data indicating deposition of a claystone-dominated succession

513 (Spekk Formation) and a near-absence of relatively coarse-grained sediment (Figure 514 12).

\subsection{Late Tithonian to Berriasian (147 - $140 \mathrm{Ma})$}

517 During the Late Tithonian to Berriasian, the Vingleia and Bremstein Fault Complexes became inactive. The footwalls and hangingwalls of both structures were capped and infilled, respectively, by deep marine claystone (Spekk Formation) (Figure 15e).

520 The rift-bounding faults, although not tectonically active, exhibited significant topography, with mud-prone submarine landslides occasionally occurring along the flanks of individual fault blocks (Figure 15e).

8. The role of salt in controlling the tectono-stratigraphic architecture and evolution of rifts

526 The presence of the pre-rift evaporite layer had a profound effect on the tectonostratigraphic development of not only the Bremstein and Vingleia fault complexes, but also that of the flanking depocentre, the Gimsan Basin. The evaporite layer acted as a temporary (i.e. Vingleia Fault Complex) or permanent (i.e. Bremstein Fault 
530 Complex) barrier to the upward propagation of basement-involved faults. The

531 Triassic evaporites facilitated the development of: (i) at-surface monoclines; (ii)

532 gravity-driven, thin-skinned extensional rafts on the steep, basinward-dipping limb of

533 the monocline either during (i.e. Bremstein Fault Complex) or after (i.e. Vingleia Fault

534 Complex) fold breaching collapse; and iii) the development of a broad, synclinal 535 growth fold within the hangingwall depocentre (Gimsan Basin) (Figure 16). Here we 536 explore the impact that the lateral variations in rift flank geometry had upon sediment source areas and pathways into the deeper basin along with how the basin geometry controlled the depositional systems found.

\subsection{Sedimentary Sources and Pathways}

541 The complex topography associated with faulting of the extensional forced fold, and

542 the subsequent rotation of the entire Bremstein Fault Complex, together produced localised intra-rift flank depocentres in the immediate hangingwall of the faults (Figures $4 \& 6$ ). This terrace-like topography comprised short, en-echelon fault segments bounding small depocentres that limited sediment delivery to the Gimsan Basin from the Bathonian to the Tithonian (i.e. c. 23 Myr) (Figure 16). In addition, the lack of footwall uplift and associated sub-aerial exposure along the footwall limited the area of erosion and the volume of sediment supplied downdip into the Gimsan Basin (Elliott et al., 2012). However, erosion of the relatively small fault blocks did locally occur; where this erosion reworked the sand-rich Garn Formation, Oxfordian turbidites where deposited in small depocentres within the fault complex (Figure 16). uplift and erosion of the footwall crest, allowing the release of significantly larger 
volumes of sediment into the adjacent depocentres (Bell et al., 2014). Although the uplift, rotation, and sub-aerial exposure had the potential to release larger volumes of sediment, the presence of the evaporite layer may have reduced the sediment volume for erosion. Particularly important in this case was the large-scale footwall collapse experienced along the crest of the Vingleia Fault Complex (Figures 4 \& 9). The salt-detached raft blocks associated with this period of footwall degradation reduced the overall topographic elevation of the footwall crest, transferring the raft blocks to structurally lower elevations and an overall lower-energy submarine environment (Figure 16). In common with the Bremstein Fault Complex, the development of this rafted topography will have led to the deposition of perched sediment accumulations along the footwall of the Vingleia Fault Complex comprised of reworked older Jurassic strata.

The deepest erosion levels along the eastern flank of the Halten Terrace are in the south, where the Vingleia Fault Complex defines the limits of the Frøya High (Figures 2,5$)$. In this area, the areal extent of the evaporite succession is not fully understood due to a lack of well control to calibrate seismic interpretation. However, Wilson et al. (2015) speculate that during evaporite deposition in the Triassic, the Frøya High most likely delimited the edge of the evaporite basin. In such a setting it is common for the less mobile evaporite and evaporite-related sediments such as anhydrites and carbonates to be deposited (c.f. Permian Zechstein Supergroup of the North Sea, Clark et al., 1998; Jackson et al., 2019). The presence of largely immobile rocks on the flanks of the Frøya High would have inhibited thin-skinned footwall collapse, thereby exposing a larger proportion of the footwall to sub-aerial erosion and allowing deeper erosion towards the south (Figure 5, 10). The lack of complex footwall topography, which would produce local accommodation along the 
579 rift flank, would have allowed sediment delivery to the Gimsan Basin; this could explain the greater sediment thicknesses found in the SE corner of the basin (Figure 11).

\subsection{Basin Geometry and Stratigraphic Style}

584

Low sediment supply from the rift flanks combined with large amount of structurally controlled accommodation mean that the Gimsan Basin was largely sediment underfilled (Figure 16). Rift flanks typically supply sediment to the hangingwall basin with this sediment derived from erosion of the immediate footwall or via antecedent drainage systems directed through the fault complex that defines the rift flank (Prosser 1993; Gawthorpe \& Leeder 2000; Ravnås et al., 2000). However, evaporite presence has reduced the sediment input by; i) reducing the amount of footwall erosion by controlling footwall elevations (c.f. Bremstein Fault Complex) and ii) by promoting footwall collapse and the formation of local accommodation that prevented the delivery of large quantities of sediment to the adjacent basin. The limited sediment supply, combined with the presence of relatively short-lived segment linkage points along the rift flanks (e.g. relay ramps; Gawthorpe et al., 1993; Leeder \& Jackson, 1993; Eliet \& Gawthorpe, 1995; Densmore et al., 2003; 2004; Elliott et al., 2012; Zhong \& Escalona 2020) prevented the development of large, long-lived sedimentary systems in the Gimsan Basin. This interpretation is supported by well data, which indicate that although present, turbidites are rare and volumetrically small. The majority of the sediment in the Gimsan Basin is shelfal siltstones (Melke Formation) and hemipelagic claystone (Spekk Formation). 
603

604

605

606

607

608

609

610

611

612

613

614

615

616

617

618

619

620

621

622

623

624

625

626

627

The topography and thus accommodation within the Gimsan Basin were controlled by the underlying structural template which, in this salt-influenced rift, defined a series of rather subtle topographic highs and lows, rather than discrete, faultbounded depocentres usually found in salt-free rifts. One potential cause for this could be the distribution of the deeper structures over the study area; i.e. in the north of the study area, where the Bremstein Fault Complex borders the Gimsan Basin, three normal faults that offset the top of the evaporite sequence are imaged (Figure 4a). In contrast, to the south, where the Vingleia Fault Complex borders the basin, only two such structures are imaged (Figure 4b). The presence of the additional fault in the north, which crosses and sub-divides the basin, controlled the topography in the Gimsan Basin. The additional fault meant that extension was spread over three structures rather than two, resulting in two shallower sub-basins rather than one relatively deep half-graben present in the south where the same amount of extension is accommodated by slip on two faults (Figures $4 \& 11$ ). The spatial distribution of these deeper structures, which may have Caledonide origins due to their NE trend (Doré et al., 1997), controlled not only the geometry of the Gimsan Basin but also the larger-scale topographic evolution of the rift flanking fault systems, with the evaporite controlling the smaller, footwall-scale development. This had important implications for sediment delivery to the rift interior.

\subsection{Comparison with other rift basins}

The presence of the pre-rift salt layer on the Halten Terrace has been demonstrated to control both the structural and stratigraphic evolution of the rift flank mainly due to the salt acting as a detachment layer decoupling the structures above and below the salt. Salt is present in a number of other basins globally with pre-,syn- and post-rift salt layers controlling the structural and sedimentary fill (Rowan 2014). The major 
salt provinces (e.g. Gulf of Mexico, Campos-Santos Basins in Brazil; Lower Congo and Kwanza basins in Africa) are in extensional systems with the salt impacting on the post-rift evolution linked to sedimentary loading from major clastic input or tilting of margin due to regional uplift and subsidence (Rowan 2014). There are few examples of a pre-rift salt layer impacting on the syn-rift evolution of the rift system but the best studied is that of the Northern North Sea in Western Europe.

The Permian Zechstein Supergroup evaporite succession dominates the structural evolution from the Triassic to Cretaceous through multiple rift phases by decoupling the basement faults from the cover, acting as a detachment level and creating variable topography due to diapirism and withdrawal basins (Stewart et al., 1997; Clark et al., 1998; Jackon \& Lewis 2013; Jackson et al., 2019). The Halten Terrace differs from the North Sea rift system in a number of ways; namely the evaporate layer is relatively thin $(<500 \mathrm{~m})$ across the basin and appears to have been much less mobile with no diapirism developed and the salt only experienced a single Jurassic rift event with no reactivation.

The thin nature and lack of mobility of the Triassic evaporate layer in the Halten Terrace may be directly to the depositional environment at that time. The Triassic salt basin on the Halten Terrace developed in a continental setting with two main phases of marine incursion to form two layers of evaporite containing a high mud content reducing the mobility of the evaporate (Jacobsen \& van Ween 1984). The topography across the Halten Terrace during the Triassic was subdued limiting lateral facies changes with only the large basement highs such as the Frøya High providing significant relief in the basin to drive facies changes (Wilson et al., 2015). The relatively thin nature, which is up to $500 \mathrm{~m}$ thick, combined with the facies-driven low mobility of the salt has meant that when supra-salt structures have formed they 
have limited in their magnitude due to the rapid welding of the salt and more brittle deformation than may be expected in a salt influenced rift system.

\section{Conclusions}

1. The structural style changes along the eastern flank of the Halten Terrace, offshore Mid-Norway from the Bremstein Fault Complex in the north where a breached monocline produced a series of horst and grabens further south strain progressively became more localised onto a single, through-going structure with footwall collapse along the Vingleia Fault Complex. The change in structural style is closely related to the presence of a pre-rift evaporite layer which acts as a detachment with syn-rift faults soling out into it and decouples structure above and below it.

2. The Bremstein Fault Complex underwent limited footwall uplift throughout the syn-rift period with relatively small-scale, localised erosion of footwall blocks supplying limited volumes of sediment downdip. Although volumetrically small, erosion of sandstone-dominated succession combined with complex structural topography of the Bremstein Fault Complex promoted the accumulation of clastic-rich localised depocentres hosted within the fault complex.

3. The Vingleia Fault Complex has undergone extensive footwall erosion combined with a phase of structural collapse. Erosion has resulted from two periods of footwall uplift, rotation and sub-aerial exposure promoting erosion 
followed by a later period of footwall collapse with block sliding on the Triassic evaporite layer. This erosion supplied sediment to both the Gimsan Basin and the adjacent hangingwall dipslope with a shoreface succession found on the flanks of the dipslope.

4. The Gimsan Basin was largely underfilled with little sediment supply from rift flanks or cross-shelf antecedent supplies. Small scale submarine fans were however, sourced from the fault scarp erosion along Vingleia Fault Complex although syn-rift sedimentation was predominantly pelagic/hemi-pelagic with occasional mud-dominated submarine slide sourced from rift flank collapse.

5. The variations in rift flank structural style have a profound influence on the sediment pathways, volumes and facies of the syn-rift sediment delivered to the evolving rift basin downdip. In contrast to basins that developed without a pre-rift evaporate layer, the variable topography along the rift flanks controlled by evaporate-influenced structural evolution facilitate local sediment supply along with small, localised accommodation space which means that syn-rift sediment accumulation will be localised along the rift flank with limited supply deeper into the rift basin.

6. Where through-going structures develop along the rift flanks, the presence of evaporite facies also will suppress the footwall topographic expression, through footwall collapse facilitated by evaporite detachment, limiting the amount of sediment supply to the basins downdip. 
702 Statoil ASA are thanked for providing funding and data for the Salt Influenced Rift 703 Basins project at Imperial College, University of Manchester and the University of 704 Bergen. In addition, we would like to thank the partners of PLXXX for permission to 705 publish this work along with Fugro MCS for permission to use and to publish the seismic data illustrated in Figures $1 \& 4$. We would like to thank in particular the

707 members of the Statoil Norwegian Sea Shallow Water Exploration Team in Harstad 708 and the Statoil Research Centre in Bergen for their help and assistance with this work. We would also like to thank Schlumberger for providing Petrel to Imperial 710 College, University of Manchester and University of Bergen. 


\section{REFERENCES}

Bell, R.E., Jackson, C., Elliott, G.M. \& Gawthorpe, R.L., 2014. Insight into the development of major rift-related unconformities from geologically constrained subsidence modelling: Halten Terrace, offshore Mid Norway. Basin Research. 26, 203- 224.

Bilal, A., McClay, K.R \& ScARSELLI, N. (2018) Fault-scarp degradation in the central Exmouth Plateau, North West Shelf, Australia In: Passive Margins: Tectonics, Sedimentation and Magmatism (Ed. by McClay, K.R. \& Hammerstein, J.A.) 476, 231-257. Geological Society, London, Special Publications.

Blystad, P., Brekke, H., Faerseth, R.B., Larsen, B.T., Skogseid, J. \& Torudbakken, B. (1995) Structural Elements of the Norwegian Continental Shelf: Part li the Norwegian Sea Region. NPD Bulletin No 8.

BrekKe, H. (2000) The Tectonic Evolution of the Norwegian Sea Continental Margin with Emphasis on the Vøring and Møre Basins. Geological Society, London, Special Publications, 167, 327-378.

Bukovics, C., Cartier, E.G., Shaw, N.D. \& Ziegler, P.A. (1984) Structure and Development of the Mid-Norway Continental Margin. In: Petroleum Geology of the North European Margin (Ed. by A. M. Spencer), 407 - 423. Graham \& Trotman, London.

Clark, J.A., SteWARt, S.A. \& CARTWRight, J. (1998) Evolution of the NW Margin of the North Permian Basin, UK North Sea. Journal of the Geological Society 155, 663-676.

Coleman, A.J., Duffy, O.B. \& Jackson, C.A-L. (2019) Growth folds above propagating normal faults. Earth-Science Reviews, 196, 102885

Corfield, S. \& ShARP, I.R. (2000) Structural Style and Stratigraphic Architecture of Fault Propagation Folding in Extensional Settings: A Seismic Example from the Smørbukk, Halten Terrace, Mid Norway. Basin Research, 12, 329-341.

Corfield, S., Sharp, I., Häger, K.-O., Dreyer, T., Underhill, J., Ole, J.M. \& Tom, D. (2001) An Integrated Study of the Garn and Melke Formations (Middle to Upper Jurassic) of the Smorbukk Area, Halten Terrace, Mid-Norway. In: Norwegian Petroleum Society Special Publications (Ed. by, Martinsen, O.J \& Dreyer, T.) Volume 10, 199-210. Elsevier.

Dalland, A., Worsley, D. \& OfStad, K. (1988) A Lithostratigraphic Scheme for the Mesozoic and Cenozoic Succession Mid - and Northern Norway, Norwegian Petroleum Directorate. NPD Bulletin No 4.

Densmore, A.L., Dawers, N.H., Gupta, S., Allen, P.A. \& Gillin, R. (2003) Landscape Evolution at Extensional Relay Zones. Journal of Geophysical Research, 108, 2273. 
Densmore, A.L., Dawers, N.H., Gupta, S., Guidon, R. \& Goldin, T. (2004) Footwall Topographic Development during Continental Extension. Journal of Geophysical Research, 109, F03001.

Dooley, T., McClay, K.R. \& Pascoe, R. (2003) 3d Analogue Models of Variable Displacement Extensional Faults: Applications to the Revfallet Fault System, Offshore Mid-Norway. In: New Insights into Structural Interpretation and Modelling (Ed. by D. A. Nieuwland), 212, 151-167. Geological Society, London, Special Publications.

Doré, A.G., Lundin, E.R., Jensen, L.N., BiRkeland, O., Eliassen, P.E. \& Fichler, C. (1999) Principal Tectonic Events in the Evolution of the Northwest European Atlantic Margin. In: Petroleum Geology of Northwest Europe: Proceedings of the 5th Conference (Ed. by A. J. Fleet \& S. A. R. Boldy), 41-61. Geological Society.

DufFY, O.B., GAWTHORPE, R.L, DOCHERTY M \& BROCKLEhURST S. H. Mobile evaporite controls on the structural style and evolution of rift basins: Danish Central Graben, North Sea (2013) Basin Research, 25, 310 - 330

Dore, A.G., Lundin, E.R., Birkeland, O., Eliassen, P.E. \& Jensen, L.N. (1997) The NE Atlantic Margin; Implications of Late Mesozoic and Cenozoic Events for Hydrocarbon Prospectivity. Petroleum Geoscience, 3, 117-131.

Ehrlich, R. \& Gabrielsen, R.H. (2004) The Complexity of a Ramp-Flat-Ramp Fault and Its Effect on Hanging-Wall Structuring: An Example from the Njord Oil Field, Offshore Mid-Norway. Petroleum Geoscience, 10, 305-317.

Eliet, P.P. \& GaWthORPE, R.L. (1995) Drainage Development and Sediment Supply within Rifts, Examples from the Sperchios Basin, Central Greece. Journal of the Geological Society, 152, 883-893.

Elliott, G.M., Wilson, P., Jackson, C.A.L., Gawthorpe, R.L., Michelsen, L. \& Sharp, I.R. (2012) The Linkage between Fault Throw and Footwall Scarp Erosion Patterns: An Example from the Bremstein Fault Complex, Offshore MidNorway. Basin Research, 24, 180-197.

Elliott, G.M., Wilson, P., Jackson, C.A.L., Gawthorpe, R.L., Michelsen, L. \& Sharp, I.R. (2012) Late syn-rift evolution of the Vingleia Fault Complex, Halten Terrace, offshore Mid-Norway; a test of rift basin tectono-stratigraphic models. Basin Research, 29 (Suppl. 1) 465- 487.

GaWthoRPE, R.L. \& HuRSt, J.M. (1993) Transfer Zones in Extensional Basins: Their Structural Style and Influence on Drainage Development and Stratigraphy. Journal of the Geological Society, 150, 1137-1152.

Faleide, J.I, Tsikalas, F., Breivik, A.J., Muelde, R., Ritzmann, O., Engen, Ø., Wilson, J. \& ELDHOLM, O. (2008) Structure and evolution of the continental margin off Norway and the Barents Sea. Episodes, 31 (1), 82 - 91 
Gawthorpe, R.L., Fraser, A.J. \& Collier, R.E.L. (1994) Sequence Stratigraphy in Active Extensional Basins: Implications for the Interpretation of Ancient BasinFills. Marine and Petroleum Geology, 11, 642-658.

Gawthorpe, R.L. \& Leeder, M.R. (2000) Tectono-Sedimentary Evolution of Active Extensional Basins. Basin Research, 12, 195-218.

Gjellberg, J., Dreyer, T., Hoie, A., TJelland, T. \& Lilleng, T. (1987) Late Triassic to Mid- Jurassic Sandbody Development on the Barents and Mid-Norwegian Shelf. In: Petroleum Geology of North West Europe (Ed. by J. Brooks \& K. W. Glennie), 1105-1129. Graham \& Trotman, London.

Jackson, C.A.L., Larsen, E., Hanslien, S. \& TJemsland, A.-E. (2011) Controls on Synrift Turbidite Deposition on the Hanging Wall of the South Viking Graben, North Sea Rift System, Offshore Norway. AAPG Bulletin, 95, 1557-1587.

JACKSON,C.A-L \& LEWIS, M.M. (2014) Structural style and evolution of a saltinfluenced rift basin margin; the impact of variations in salt composition and the role of polyphase extension Basin Research, 26, 81 - 102

Jackson, C.A-L., Elliott, G.M., Royce-rogers, E., Gawthorpe, R.L. \& Aas, T.E. (2019) Salt thickness and composition influence rift structural style, northern North Sea, offshore Norway. Basin Research 31 (3), 514 - 538

KANE, K.E., JACKSON, C.A.-L. \& LARSEN, E. (2010) Normal fault growth and faultrelated folding in a salt-influenced rift basin: south Viking Graben, offshore Norway. Journal of Structural Geology, 32, 490-506.

Jacobsen, V.W. \& van Veen, P. (1984) The Triassic Offshore Norway North of 62n. In: Petroleum Geology of the North European Margin (Ed. by A. M. Spencer), 317-327. Graham \& Trotman.

LEEDER, M.R. \& JACKSON, J.A. (1993) The Interaction between Normal Faulting and Drainage in Active Extensional Basins, with Examples from the Western United States and Central Greece. Basin Research, 5, 79-102.

McLeod, A.E. \& UNDERHILL, J.R. (1999) Processes and Products of Footwall Degradation, Northern Brent Field, Northern North Sea. In: Petroleum Geology of Northwest Europe: Proceedings of the 5th Conference (Ed. by A. J. Fleet \& S. A. R. Boldy), Geological Society, London, 91-106.

Marsh, N., Imber, J., Holdsworth, R.E., Brockbank, P. \& Ringrose, P. (2010) The Structural Evolution of the Halten Terrace, Offshore Mid-Norway: Extensional Fault Growth and Strain Localisation in a Multi-Layer Brittle \& Ductile System. Basin Research, 22, 195-214.

Martinius, A.W., KaAs, I., Nss, A., Helgesen, G., Kurefjord, J.M., Leith, D.A., Ole, J.M. \& Tom, D. (2001) Sedimentology of the Heterolithic and Tide-Dominated Tilje Formation (Early Jurassic, Halten Terrace, Offshore Mid-Norway). In: 
Norwegian Petroleum Society Special Publications (Ed. by Martinsen, O.J \& Dreyer, T.) Volume 10, 103-144. Elsevier.

Martinius, A.W., Ringrose, P.S., Brostrom, C., Elfennbein, C., Naess, A. \& Ringas, J.E. (2005) Reservoir Challenges of Heterolithic Tidal Sandstone Reservoirs in the Halten Terrace, Mid-Norway. Petroleum Geoscience, 11, 3-16.

Messina, C., Nemec, W., Martinius, A.W. \& Elfenbein, C. (2014) The Garn Formation (Bajocian-Bathonian) in the Kristin Field, Halten Terrace: its origin, facies architecture and primary heterogeneity model In: From Depositional Systems to Sedimentary Successions on the Norwegian Continental Margin (Ed. by Martinius, A.W., Ravnås, R., Howell, J.A. \& Wonham, J.P.) 513 - 550. International Association of Sedimentologists/John Wiley \& Sons, Ltd

NPD Factpage Fenja Field https://factpages.npd.no/en/field/pageview/all/31164879 Accessed August 2020

Nøttvedt, A., Berge, A.M., Dawers, N.H., F/erseth, R.B., Häger, K.O., Mangerud, G. \& Puigdefabregas, C. (2000) Syn-Rift Evolution and Resulting Play Models in the Snorre-H Area, Northern North Sea. Geological Society, London, Special Publications, 167, 179-218.

Pascoe, R., Hooper, P.R., Storhaug, K. \& Harper, H. (1999) Evolution of Extensional Styles at the Southern Termination of the Nordland Ridge, MidNorway: A Response to Variations in Coupling above Triassic Salt. In: Petroleum Geology of Northwest Europe: Proceedings of the 5th Conference (Ed. by J. A. Fleet \& S. A. R. Boldy), 83-90. Geological Society of London.

Penge, J., Taylor, B., Huckerby, J.A. \& Munns, J.W. (1993) Extension and Salt Tectonics in the East Central Graben. In: Petroleum Geology of Northwest Europe: Proceedings of the 4th Conference (Ed. by J. R. Parker), 1197-1209. Geological Society of London, London.

Prosser, S. (1993) Rift-Related Linked Depositional Systems and Their Seismic Expression. In: Tectonics and Seismic Sequence Stratigraphy (Ed. by G. D. Williams \& A. Dobb), 71, 35-66. Geological Society, London, Special Publications.

Provan, D. (1992) Draugen Oil Field, Haltenbanken Province, Offshore Norway. In: Giant Oil and Gas Fields of the Last Decade 1978-1988 (Ed. by M. T. Halbouty), AAPG Memoir 54, 371-382. AAPG, Tulsa.

Ravnas, R. \& Steel, R.J. (1998) Architecture of Marine Rift-Basin Successions. AAPG Bulletin, 82, 110-146.

RavnÅs, R., Nøttvedt, A., Steel, R.J. \& Windelstad, J. (2000) Syn-Rift Sedimentary Architectures in the Northern North Sea. In: Dynamics of the Norwegian Margin (Ed. by A. Nottvedt), 167, 133-177. Geological Society, London, Special Publications. 
Roberts, A.M., Kusznir, N.J., Yielding, G. \& Beeley, H. (2019) Mapping the bathymetric evolution of the Northern North Sea: from Jurassic synrift archipelago through Cretaceous-Tertiary post-rift subsidence. Petroleum Geoscience, 25, 306-321.

RowAN, M.G. (2014) Passive-margin salt basins: hyperextension, evaporite deposition, and salt tectonics. Basin Research, 26, 154-182

Richardson, N.J., UnderhILL, J.R. \& LEWIS, G. (2005) The Role of Evaporite Mobility in Modifying Subsidence Patterns During Normal Fault Growth and Linkage, Halten Terrace, Mid-Norway. Basin Research, 17, 203-223.

RoberTs, A.M. \& YieLDiNG, G. (1991) Deformation around basin-margin faults in the North Sea/mid-Norway rift In: The Geometry of Normal Faults (Ed. by Roberts, A.M., Yielding, G. \& Freeman, B.), 56, 61 - 78, Geological Society Special Publication, London

Roberts, D.G., Thompson, M., Mitchener, B., Hossack, J., Carmichael, S. \& BJoRnSETH, H.M. (1999) Palaeozoic to Tertiary Rift and Basin Dynamics: MidNorway to the Bay of Biscay - a New Context for Hydrocarbon Prospectivity in the Deep Water Frontier. In: Petroleum Geology of Northwest Europe (Ed. by J. A. Fleet \& S. A. R. Boldy), 7-40. Geological Society of London.

SANDWELL, D.T. \& SMITH, W.H.F. (1997) Marine Gravity Anomaly from Geosat and Ers 1 Satellite Altimetry. Journal of Geophysical Research, 102, 10039-10054.

Stewart, S.A., Ruffell, A.H. \& Harvey, M.J. (1997) Relationship between basement-linked and gravity-driven fault systems in the UKCS salt basins. Marine and Petroleum Geology, 14, 581-604.

Slagstad, T., DavidSEn, B. \& Daly, J.S. (2011) Age and Composition of Crystalline Basement Rocks on the Norwegian Continental Margin: Offshore Extension and Continuity of the Caledonian-Appalachian Orogenic Belt. Journal of the Geological Society, 168, 1167-1185.

Swiecicki, T., GibBS, P.B., Farrow, G.E. \& Coward, M.P. (1998) A Tectonostratigraphic Framework for the Mid-Norway Region. Marine and Petroleum Geology, 15, 245-276.

TavanI, S. \& Granado, P. (2015) Along-strike evolution of folding, stretching and breaching of supra-salt strata in the Plataforma Burgalesa extensional forced fold system (northern Spain) Basin Research, 27 (4), 573 - 585.

Tavani, S., Balsamo, F. \& Granado, P. (2018) Petroleum system in supra-salt strata of extensional forced-folds: A casestudy from the Basque-Cantabrian basin (Spain) Marine and Petroleum Geology, 96, 315 - 330

Underhill, J.R., Sawyer, M.J., Hodgson, P., Shallcross, M.D. \& Gawthorpe, R.L. (1997) Implications of Fault Scarp Degradation for Brent Group Prospectivity, Ninian Field, Northern North Sea. AAPG Bulletin, 81, 999-1022. 
Welbon, A.I.F., Brockbank, P.J., Brunsden, D. \& Olsen, T.S. (2007) Characterizing and Producing from Reservoirs in Landslides: Challenges and Opportunities. In: Structurally Complex Reservoirs (Ed. by S. J. Jolley, D. Barr, J. J. Walsh \& R. J. Knipe), 292, 49-74. Geological Society Special Publication, London.

Wilson, P., Elliott, G.M., GaWthorpe, R.L., Jackson, C.A.L., Michelsen, L.M. \& SHARP, I.R. (2013) Structure and Growth of an Evaporite-Detached Normal Fault Array: The Southern Bremstein Fault Complex, Offshore Mid-Norway. Journal of Structural Geology, 51, 74 - 91

Wilson, P., Elliott, G.M., Gawthorpe, R.L., Jackson, C.A.-L. \& SharP, I.R. (2015) Lateral variation in structural style along an evaporite-influenced rift fault system in the Halten Terrace, Norway: the influence of basement structure and evaporite facies. Journal of Structural Geology, 79, 10-123.

WithJaCK, M.O., MeisLing, K. \& RusselL, L. (1989) Forced Folding and BasementDetached Normal Faulting in the Haltenbanken Area, Offshore Norway. In: Extensional Tectonics and Stratigraphy of the North Atlantic Margins (Ed. by A. Tankard \& H. R. Balkwill), AAPG Memoir 46, 567-575. AAPG.

Withuack, M.O., Olson, J. \& Peterson, E. (1990) Experimental Models of Extensional Forced Folds. AAPG Bulletin, 74, 1038-1054.

YIELDING, G. (1990) Footwall uplift associated with Late Jurassic normal faulting in the northern North Sea. Journal of the Geological Society, 147, 219-222.

Zastrozhnov, D., Gernigon, L., Gogin, I., Planke, S., Abdelmalak, M.M., Polteau, S., FALEIDE, J.I., MANTON, B. \& MYKLEBUSt, R. (2020) Regional structure and polyphased Cretaceous-Paleocene rift and basin development of the midNorwegian volcanic passive margin. Marine and Petroleum Geology, 115, 104269

ZHONG, X \& Escalona, A. (2020) Evidence of rift segmentation and controls of Middle to Late Jurassic synrift deposition in the Ryggsteinen ridge area, northern North Sea AAPG Bulletin, 104, 1531 - 1565

VAN DER ZWAN, C.J. (1990) Palynostratigraphy and Palynofacies Reconstruction of the Upper Jurassic to Lowermost Cretaceous of the Draugen Field, Offshore Mid Norway. Review of Palaeobotany and Palynology, 62, 157-186. 

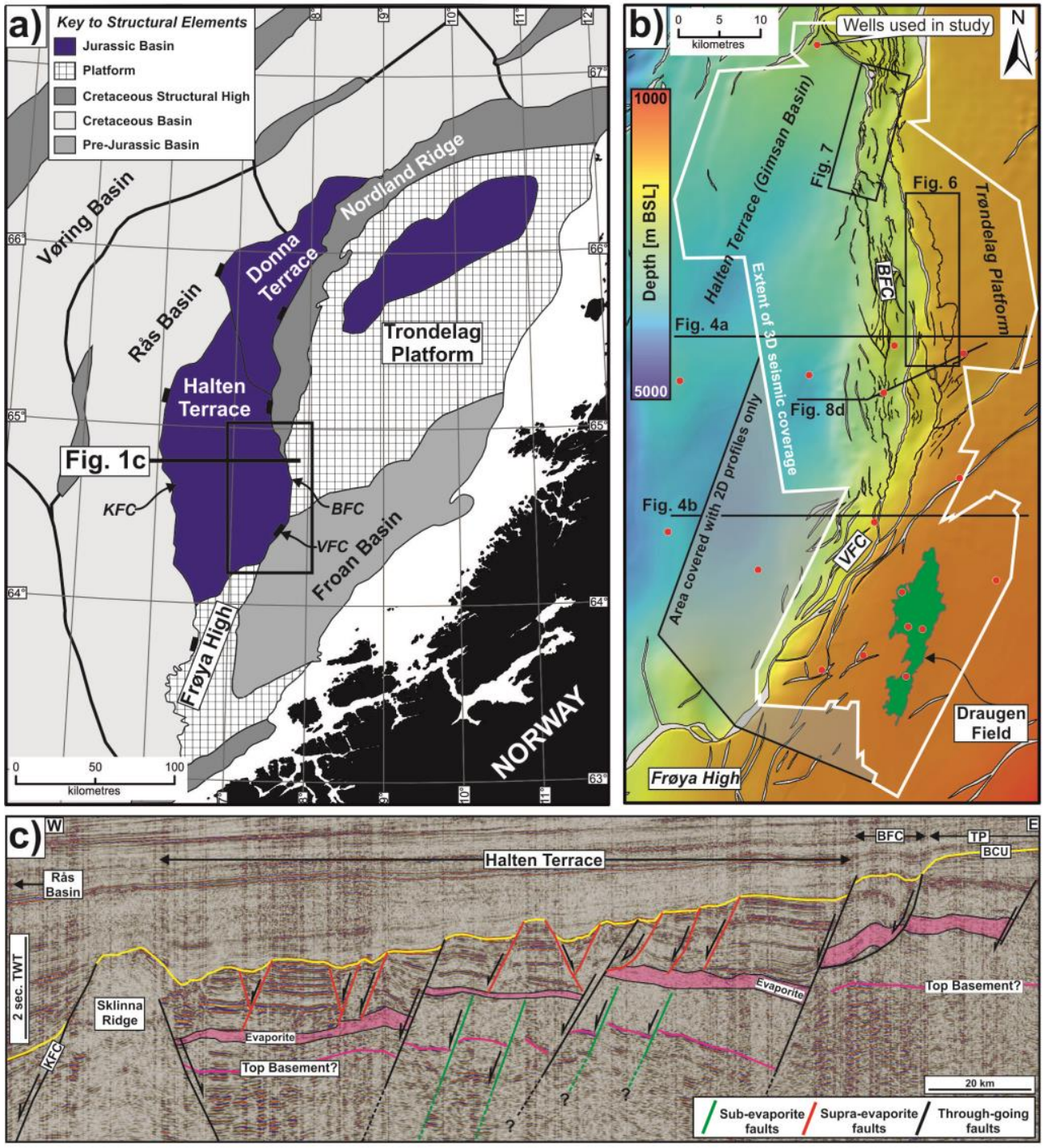

Figure 1: a) Structural elements map of the Mid-Norwegian Shelf showing the location of the Halten Terrace (modified from Blystad et al., 1998) b) Base Cretaceous Unconformity depth structure map showing the study area along the eastern flank of the Halten Terrace. The white polygon outlines the areal extent of $3 \mathrm{D}$ seismic reflection data used in the study with the grey polygon delimiting the region where only $2 \mathrm{D}$ profiles were used. The location of the wells used in the study are highlighted also along with the outline of the Draugen oil field. BFC: Bremstein Fault Complex. VFC: Vingleia Fault Complex. c) Regional seismic reflection profile across the Halten Terrace showing the influence of the evaporite upon the fault distribution (see Figure 1a for location). BFC: Bremstein Fault Complex. KFC: Klakk Fault Complex. TP: Trondelag Platform. 


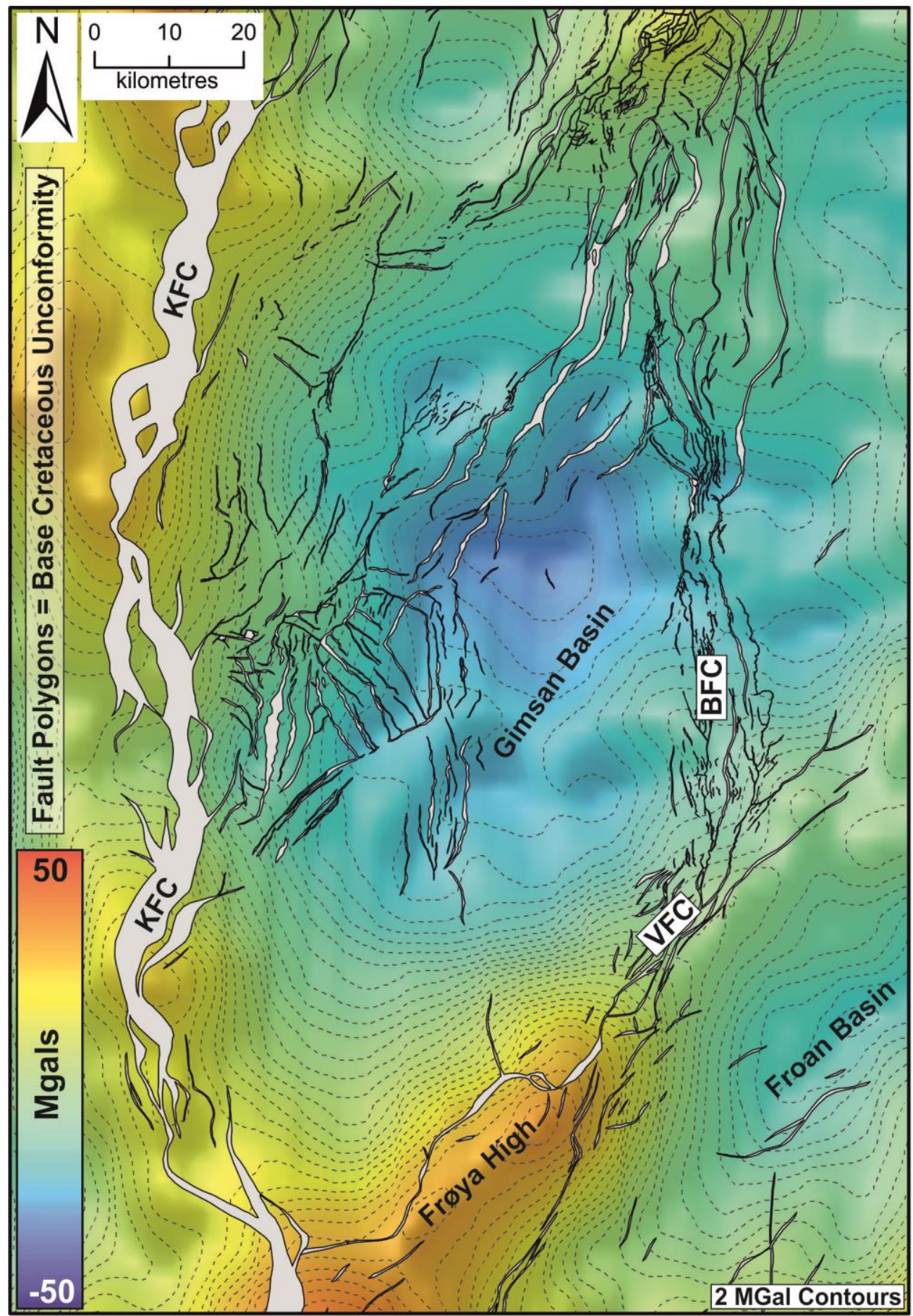

1014 Figure 2: Free-Air gravity anomaly map based upon satellite observations (Sandwell 1015 and Smith 1997) over the Halten Terrace showing the large positive anomaly 1016 associated with the Frøya High which is bound to the north by the Vingleia Fault 1017 Complex while the Bremstein Fault Complex is associated with a gravity low. BFC: 1018 Bremstein Fault Complex. KFC: Klakk Fault Complex. VFC: Vingleia Fault Complex. 


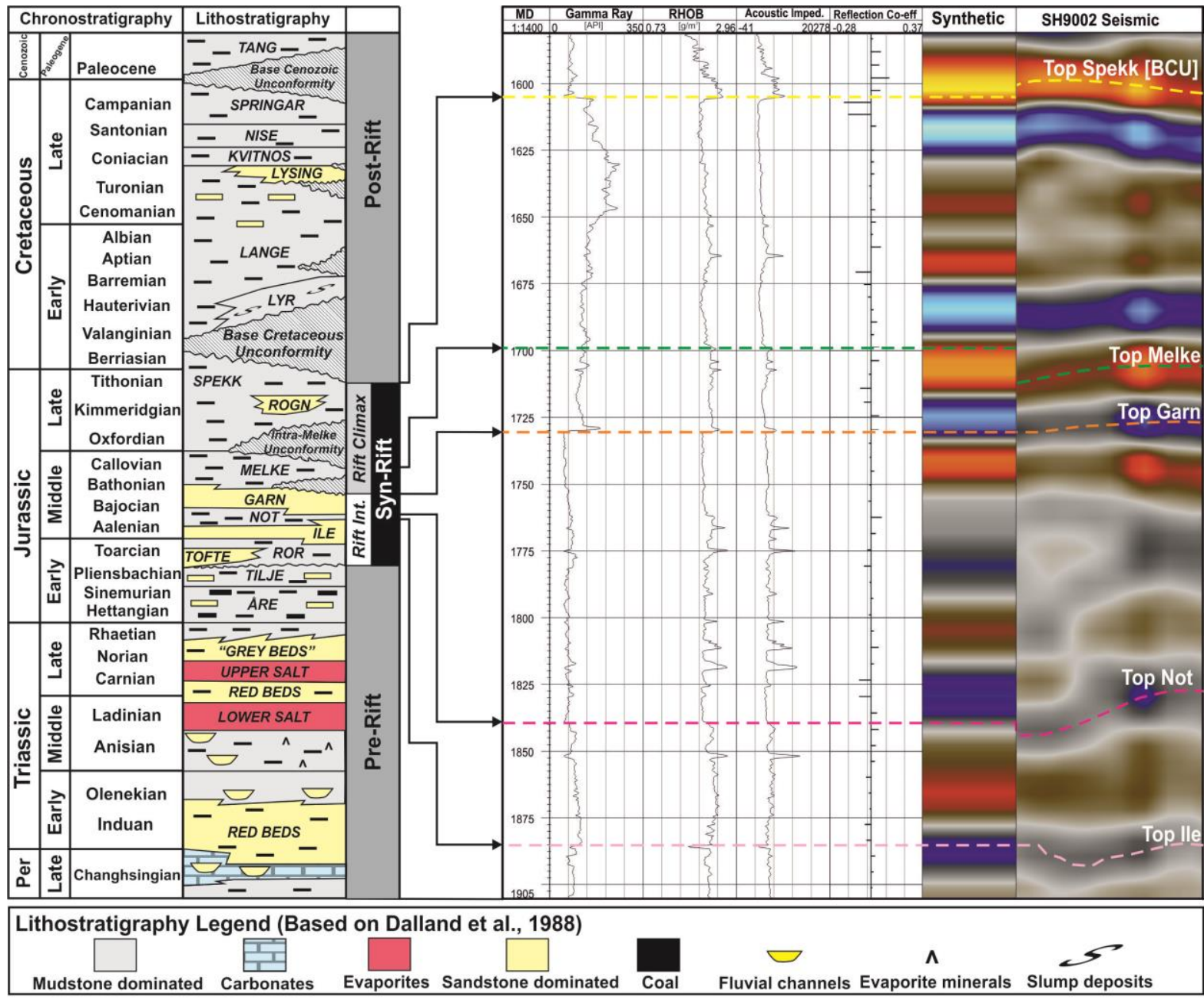

1021 Figure 3: Stratigraphic column for the Halten Terrace based upon Dalland et al., 1022 (1988) with a synthetic seismogram for well 6407/9-8 demonstrating the correlation 1023 between the key stratigraphic markers identified in the well with seismic reflection events. 

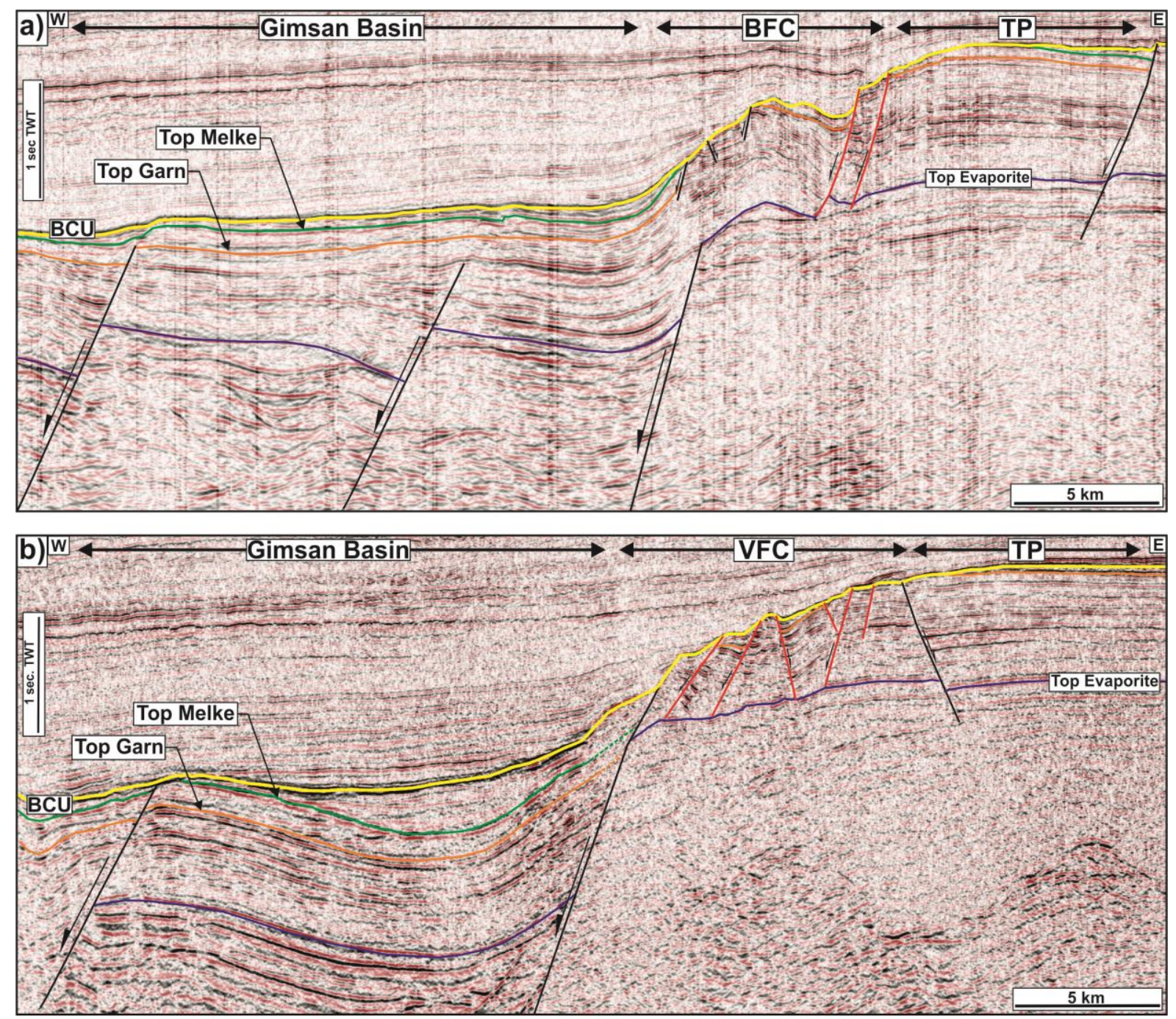

Figure 4: Two E-W seismic sections across the eastern margin of the Halten Terrace 1027 the upper section shows the breached monocline structure of the Bremstein Fault 1028 Complex (BFC). The lowermost section shows the though-going structure of the 1029 Vingleia Fault Complex (VFC) along with the zone of footwall collapse along the 1030 western edge of the footwall. Fault planes are colour coded as per Figure 1c. TP: 1031 Top Evaporite. See Figure 1b for profile location. 

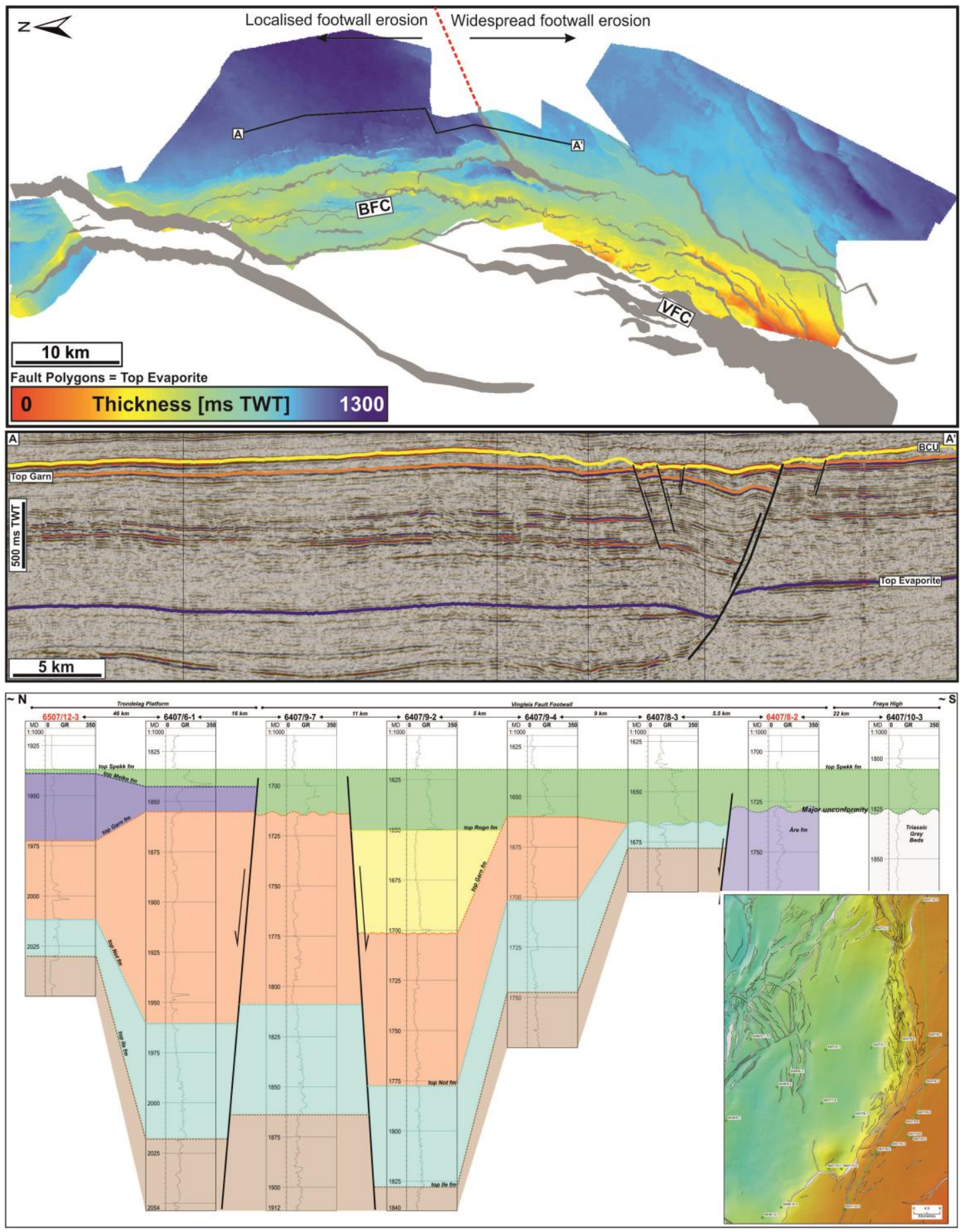

Figure 5: Top Evaporite to BCU Isochron along the eastern flank of the Halten Terrace showing the difference in erosion level from south to north. The largest amount of footwall erosion is found in the south which progressively increases towards the Vingleia Fault complex footwall crest whereas the Bremstein Fault Complex has a relatively uniform thickness until the reaching the fault complex itself. A prominent NE-SW striking fault (imaged on profile A-A') seperates the eastern rift flank into two distinct areas with widespread footwall erosion in the south and an area of more localised footwall erosion to the north. BFC: Bremstein Fault Complex. VFC: Vingleia Fault Complex. 

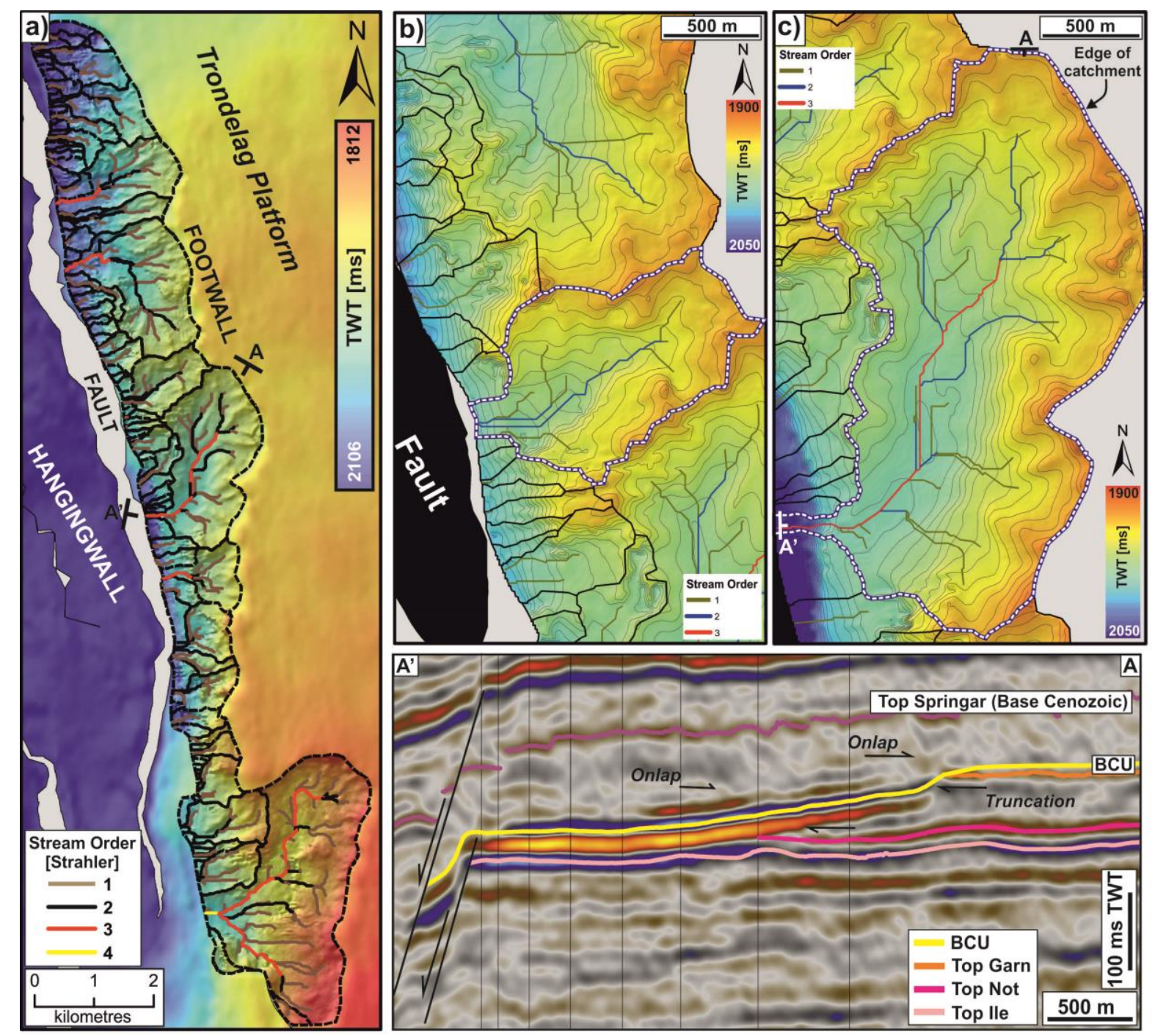

Figure 6: a) Base Cretaceous Unconformity elevation map of the Bremstein Fault 1044 Complex footwall with catchments and stream networks highlighted together with the 1045 main fault segment (in grey). A-A': Axial seismic section along footwall catchment 1046 showing the concave down incisonal nature of the system which is hosted within the 1047 sandstone-dominated Garn Formation and progressive onlap of overlying 1048 Cretaceous. b) Time structure map of linear catchment characterised by low Strahler 1049 stream order. c) Time structure map of curved catchment characterised by higher stream orders. 

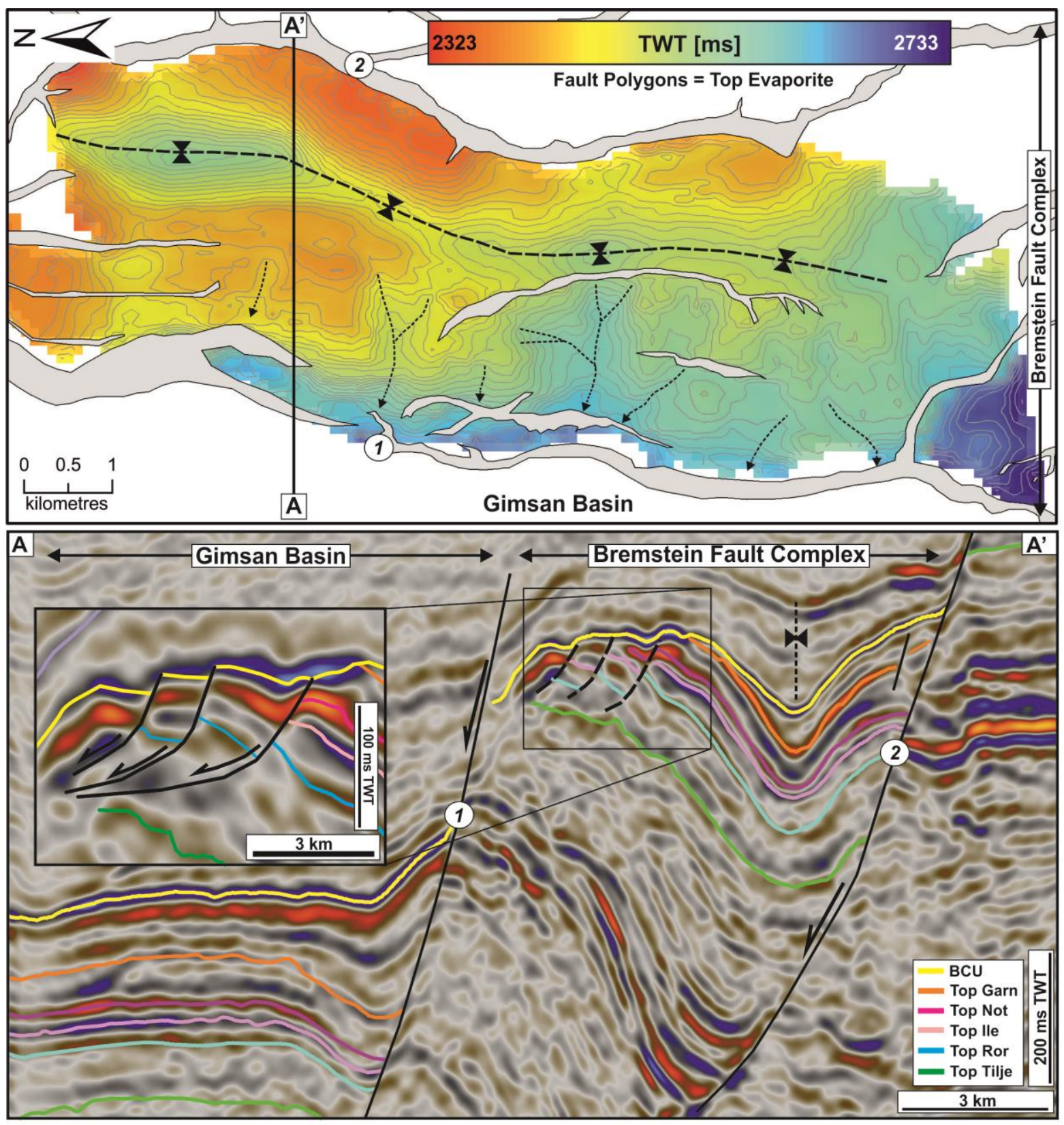

Figure 7: Base Cretaceous time-structure map of an individual fault block found 1053 within the Bremstein Fault Complex exhibiting a number of erosional features along 1054 the western edge of the footwall. Profile A-A' shows how the crestal collapse is 1055 lithologically controlled with the mudstone-dominated Ror Formation acting as a detachment for the crestal collapse. 

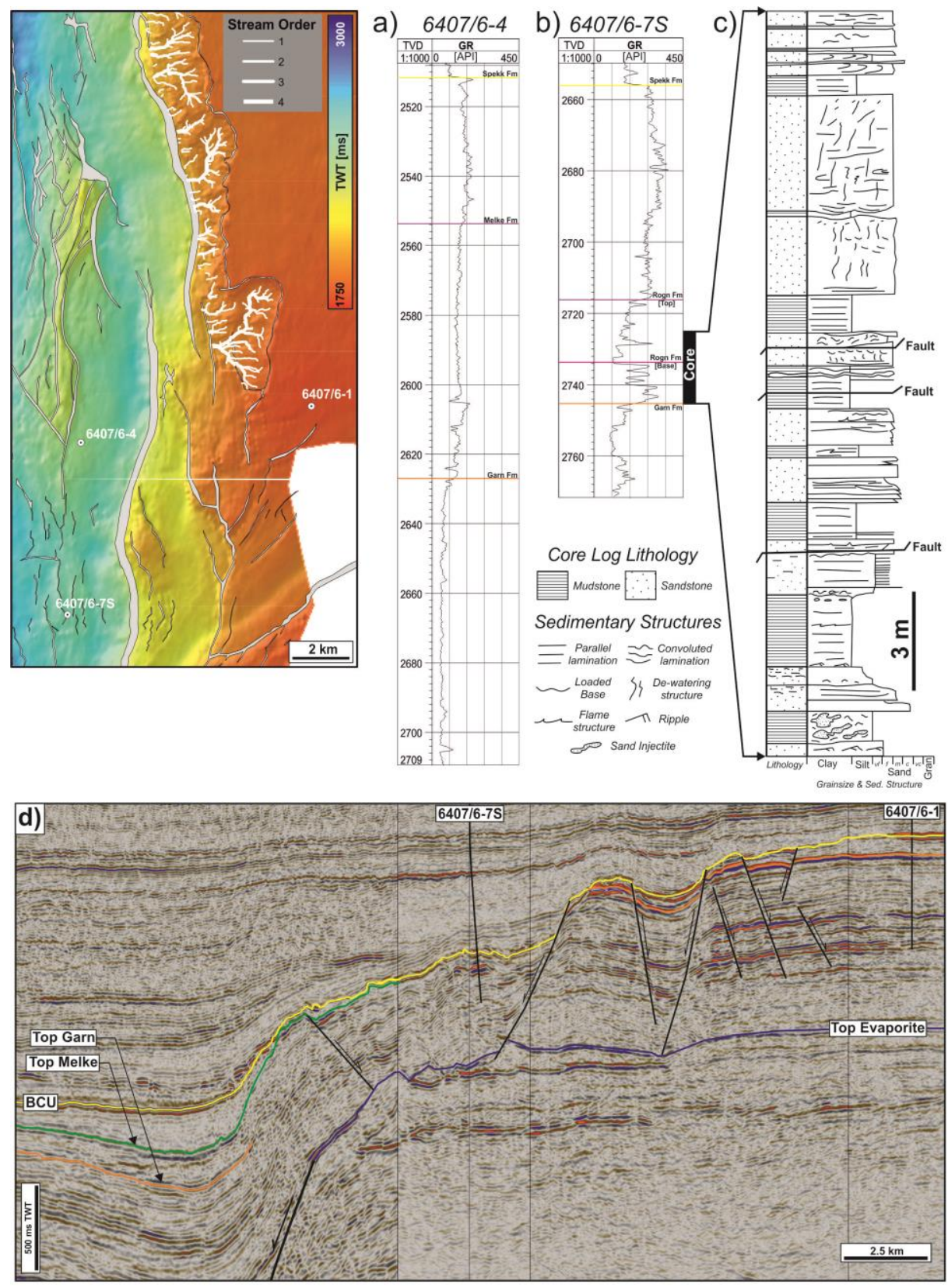

Figure 8: a) Gamma ray wireline log from well 6407/6-4 (see map left for location) which is located in the hangingwall of an elongate horst block within the Bremstein Fault Complex. The well encountered over $100 \mathrm{~m}$ of Melke Formation siltstone with no indicaton of coarse clastic into the fault complex throughout the Late Jurassic. b) Gamma ray wireline log from well 6407/6-7S (see map left for location) which encountered a $44 \mathrm{~m}$ thick Late Jurassic Rogn Formation package. c) 1:100 scale graphic sedimentological log from $17 \mathrm{~m}$ through the Late Jurassic of 6407/6-7S showing the presence of thick massive sandstone beds within the Rogn Formation. These coarse clastic beds are thought to be derived from footwall erosion update from the well (see map for location of well and footwall erosion catchments). d) Seismic section from Trondelag Platform across the Bremstein Fault Complex to the Gimsan Basin showing the structural location for well 6407/6-7S, which is hosted within the breached monocline structure. 

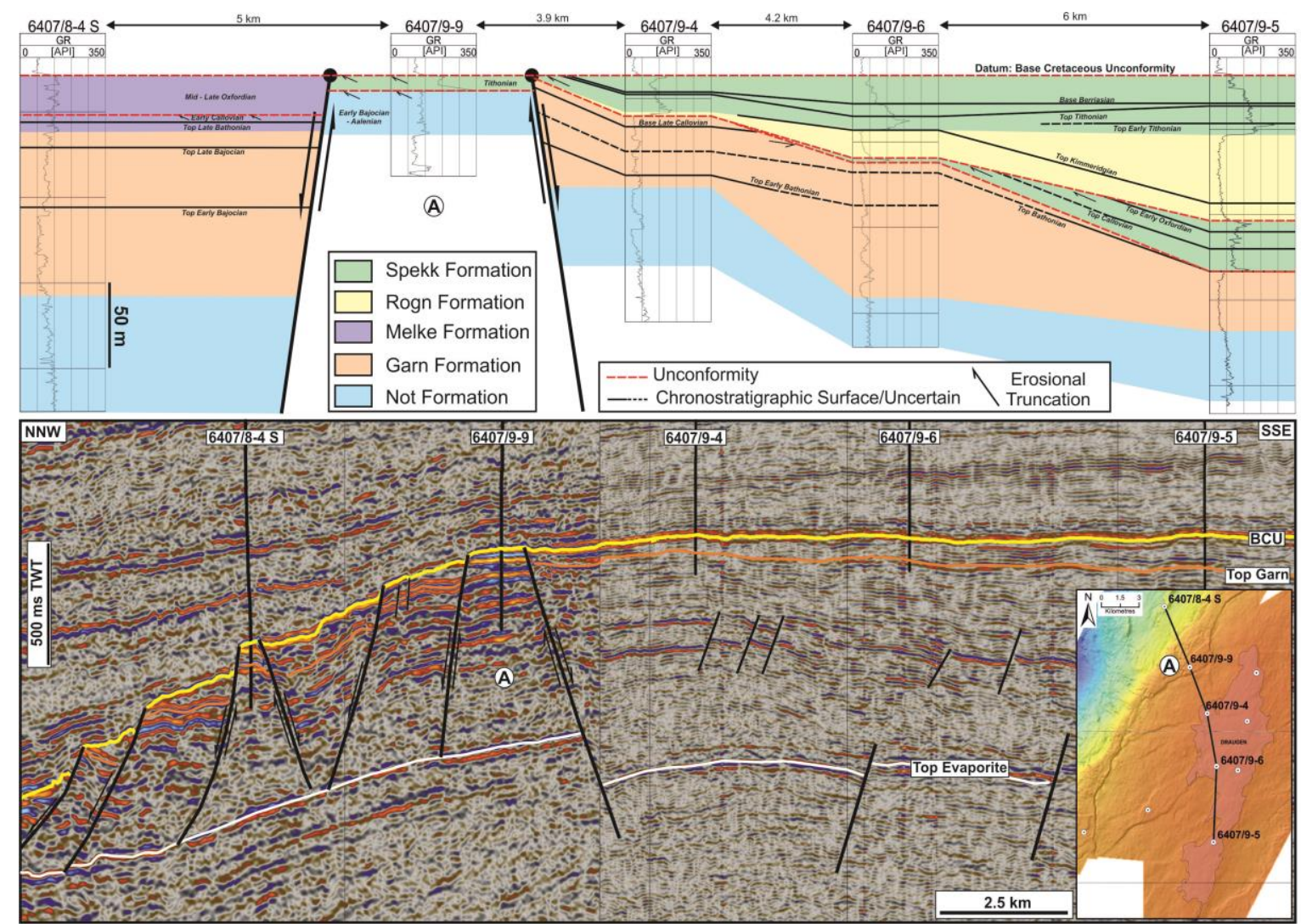

1072 Figure 9: Stratigraphic correlation of Jurassic succession from selected wells along a 1073 broadly NW-SE along the footwall of the Vingleia Fault Complex with corresponding 1074 arbitrary seismic profile which helped to constrain the underlying structure along the 1075 panel. Key biostratigraphically constrained time lines are shown. The panel exhibits 1076 the progressive onlap of the Late Jurassic onto a prominent composite unconformity 1077 surface which downcuts towards the footwall crest. In addition, the perseveration of 1078 Oxfordian within the rafted block helps to constrain the timing of the footwall collapse. 

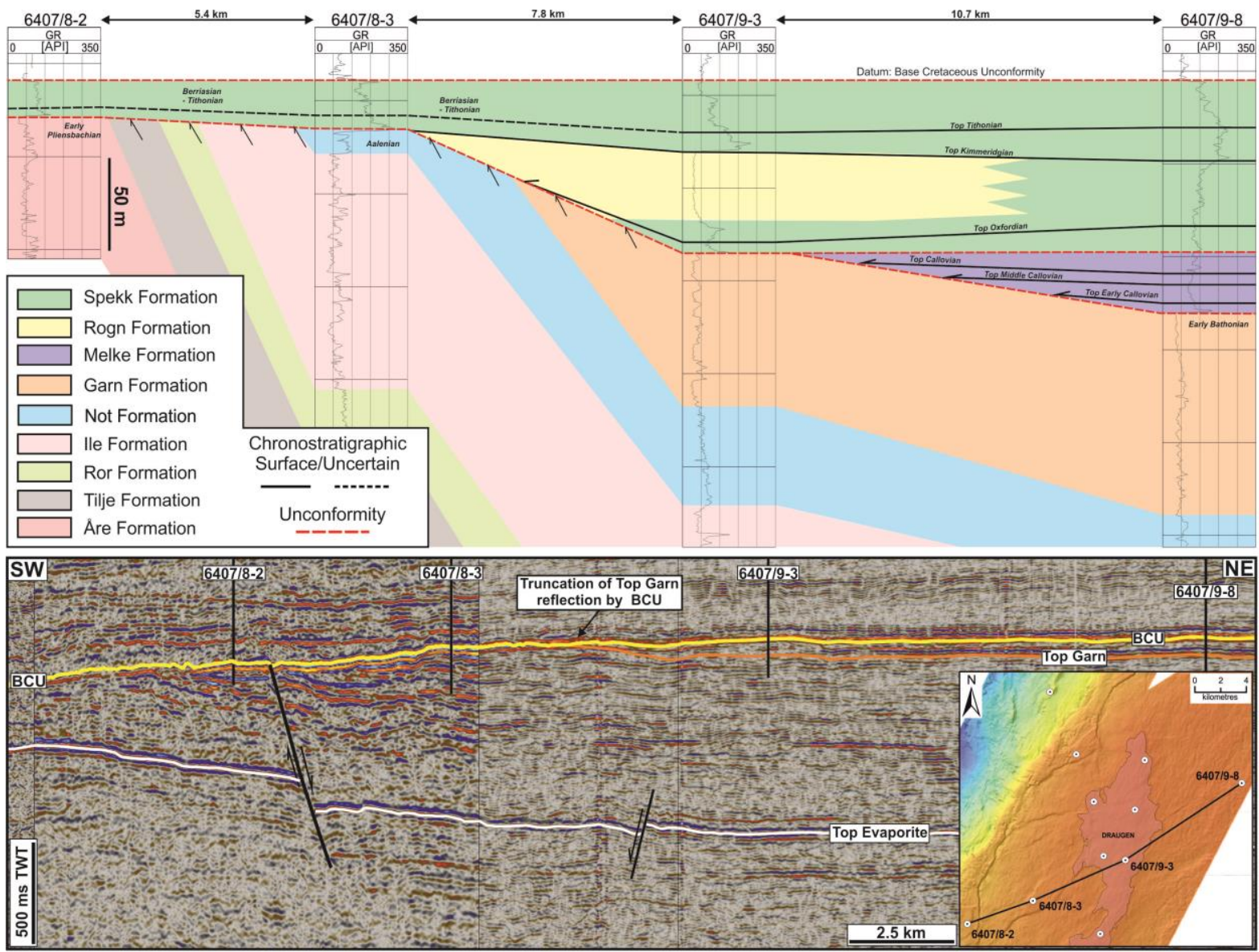

Figure 10: Stratigraphic correlation of Jurassic succession from selected wells along a broadly NE-SW along the footwall of the Vingleia Fault Complex with corresponding arbitrary seismic profile which helped to constrain the underlying structure along the panel. Key biostratigraphically constrained time lines are shown. The panel shows the progressive downcutting of the Callovian/Oxfordian composite unconformity to the south where older units subcrop at that erosion level. 


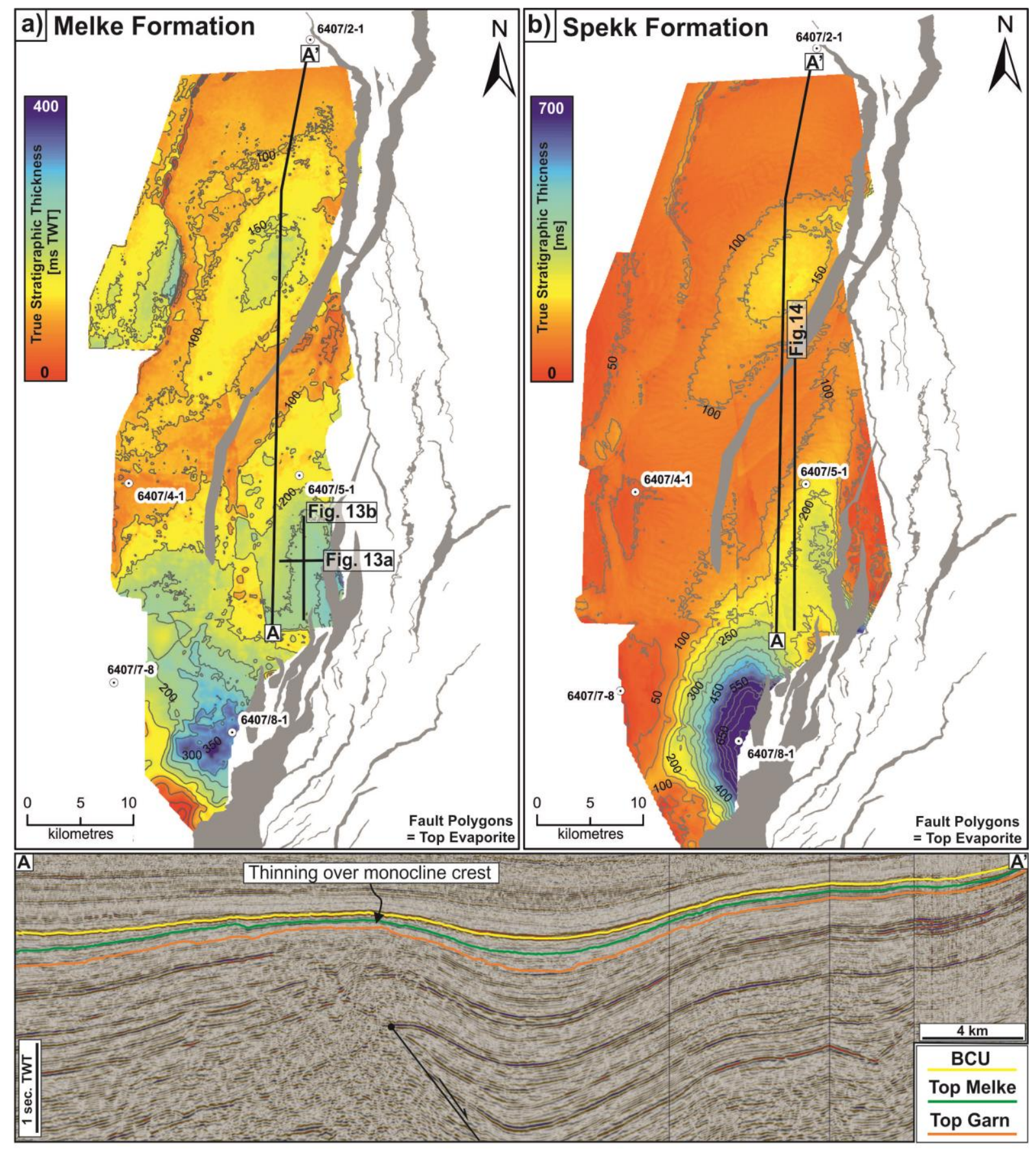

Figure 11: a) Melke Formation isochron from the Gimsan Basin with Top Evaporite fault polygon and key wells highlighted. Three distinct depocentres are recognised with sediment thicknesses up to 400 ms TWT located within the hangingwall of major faults. b) Spekk Formation isochron from Gimsan Basin with Top Evaporite fault polygons and key wells highlighted. Sediment thicknesses are greater than those found in the Melke Formation with up to 700 ms TWT found in the immediate SW corner of the basin adjacent to the Vingleia Fault Complex. Typical Spekk Formation thicknesses are around 100 ms TWT across the basin with up to $150 \mathrm{~ms}$ TWT found within subtle NE-SW orientated depocentres. Profile A-A' is a N-S oriented profile along the basin axis which shows the control that a NE-SW striking structure at depth has upon the Middle to Late Jurassic succession. 


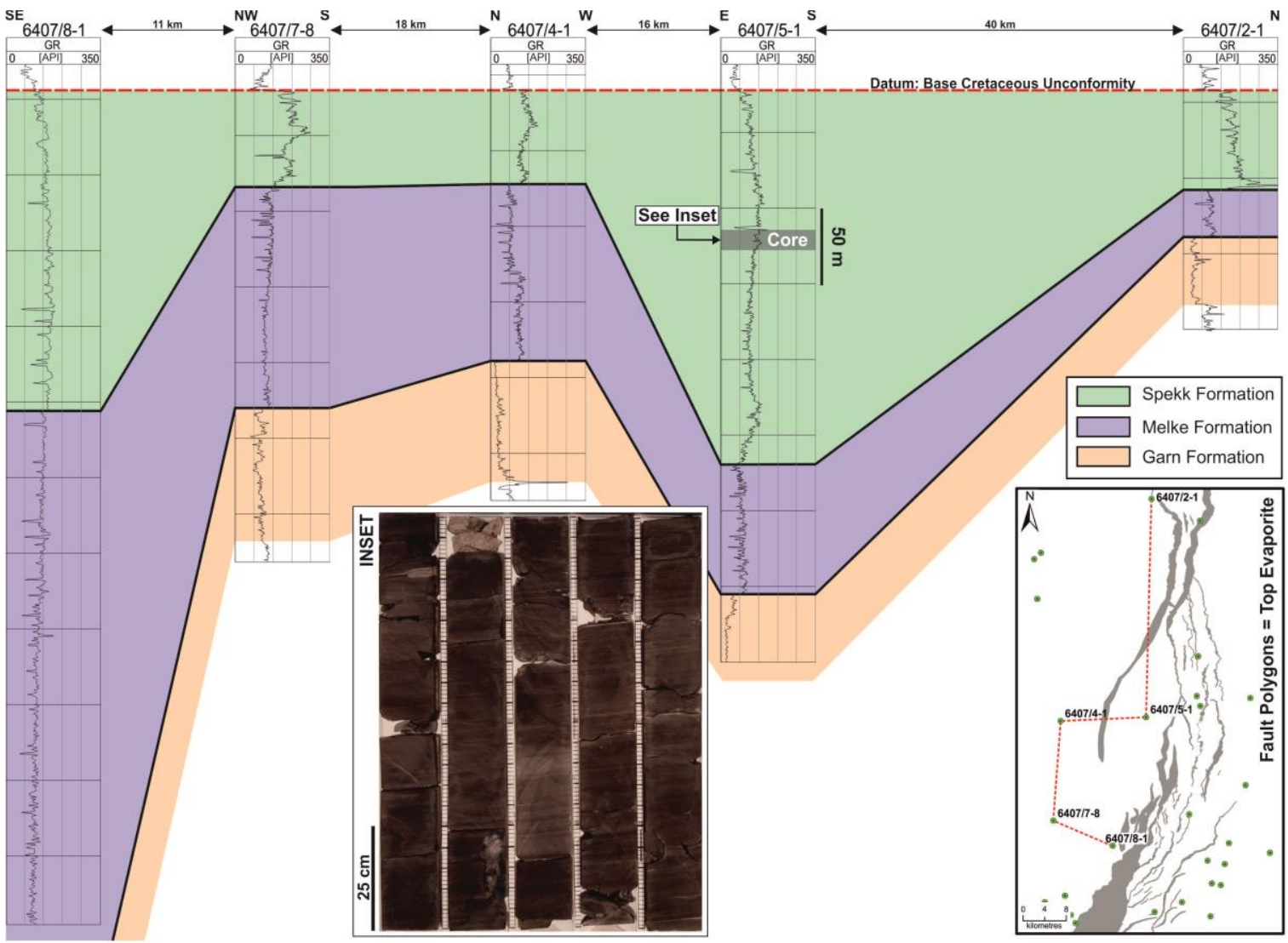

Figure 12: Broadly N-S orientated axial lithostratigraphic correlation panel from the Gimsan Basin showing the variations in the Melke and Spekk Formations within the basin. The thickest Melke Formation is found in the SW corner in 6407/8-1 while the thickest Spekk Formation is found further north in 6407/5-1 and comprises shale succession, based upon Gamma Ray log signature and core samples (see inset). 

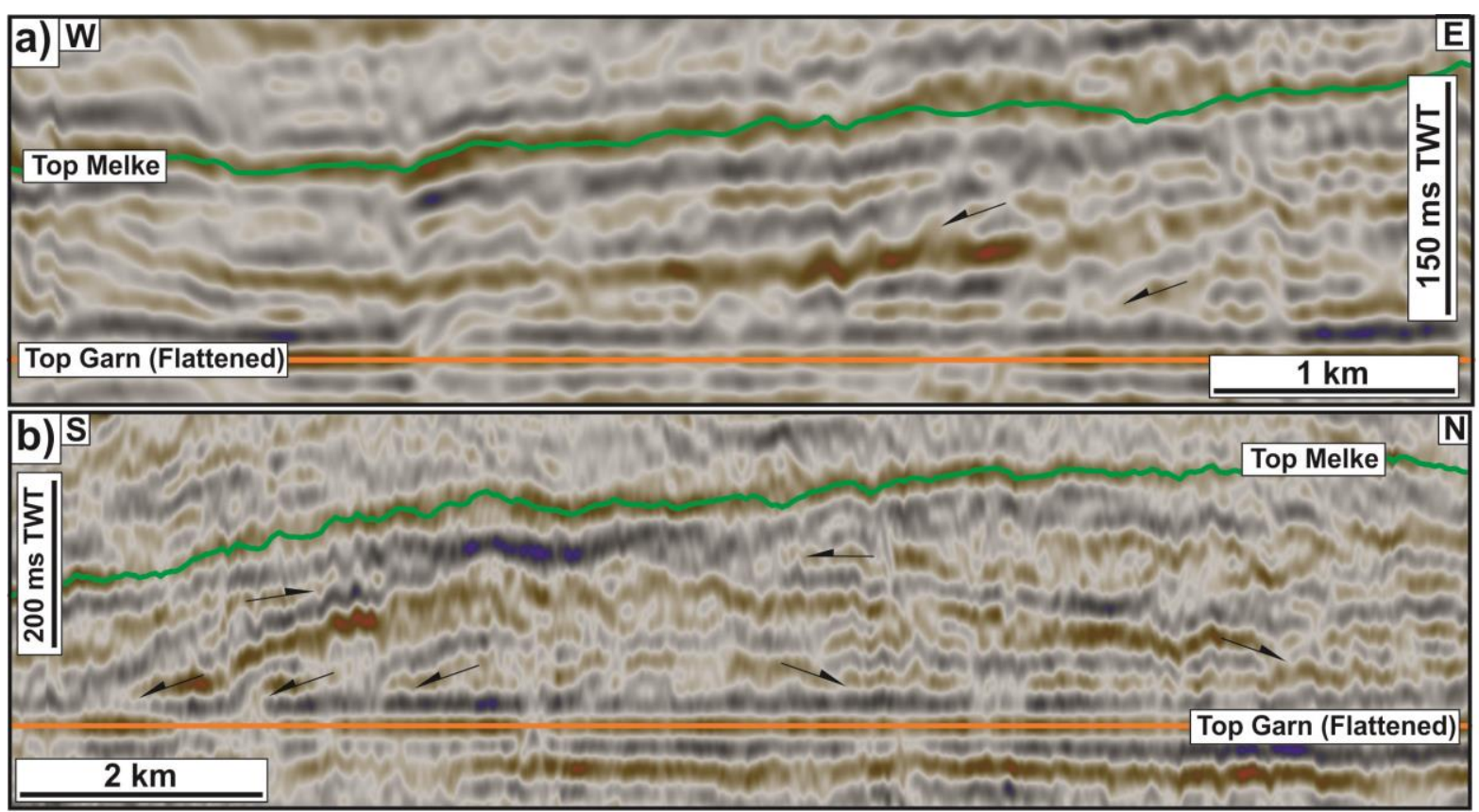

1108 Figure 13: a) E-W orientated seismic profile from the Gimsan Basin, flattened on Top 1109 Garn Formation to highlight the downlapping nature of the Melke Formation which 1110 thickens towards the Vingleia Fault Complex, which is located to the right of the 1111 section. b) N-S seismic profile taken broadly parallel to the Vingleia Fault Complex, 1112 again flattened on Top Garn, showing the mounded nature of the Melke Formation in 1113 this area. The onlaps onto the mound flanks suggest positive topography at time of deposition and these interpreted as submarine fan systems. See Figure 11 for location of $a \& b$. 

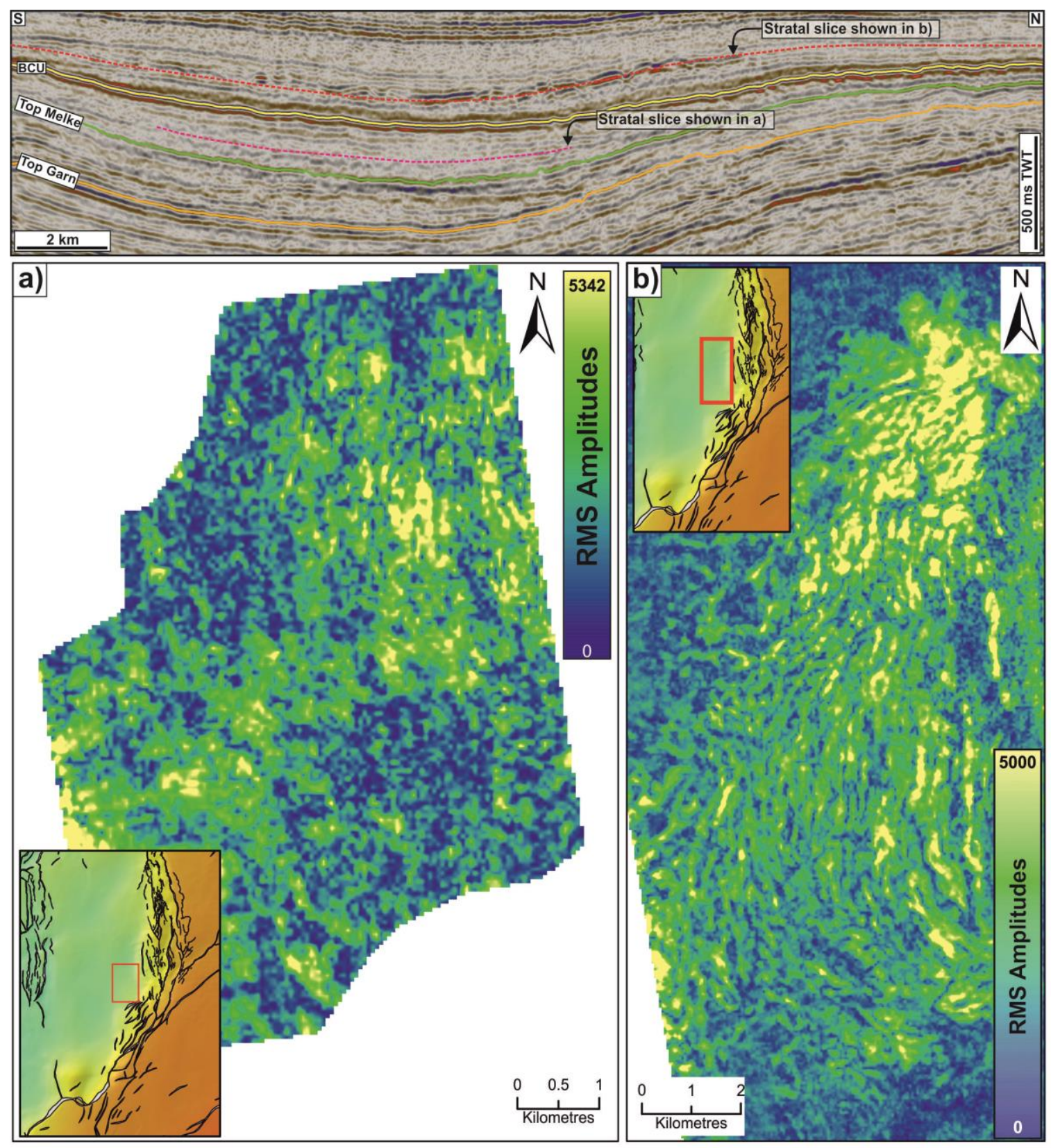
1117 Figure 14: a) RMS amplitude extraction from intra-Spekk reflection event showing 1119 Complex in the east (See inset map for location). b) RMS extraction from Early 1120 Cretaceous reflection event (highlighted on N-S seismic profile) described by Løseth 1121 et al., (2011) as a large slope failure complex comprised of Spekk Formation shale 1122 which exhibits a similar curvi-linear pattern as seen in the intra-Spekk event 1123 suggesting a slope failure origin for those features. See Figure 11 for location of N-S 1124 profile. 


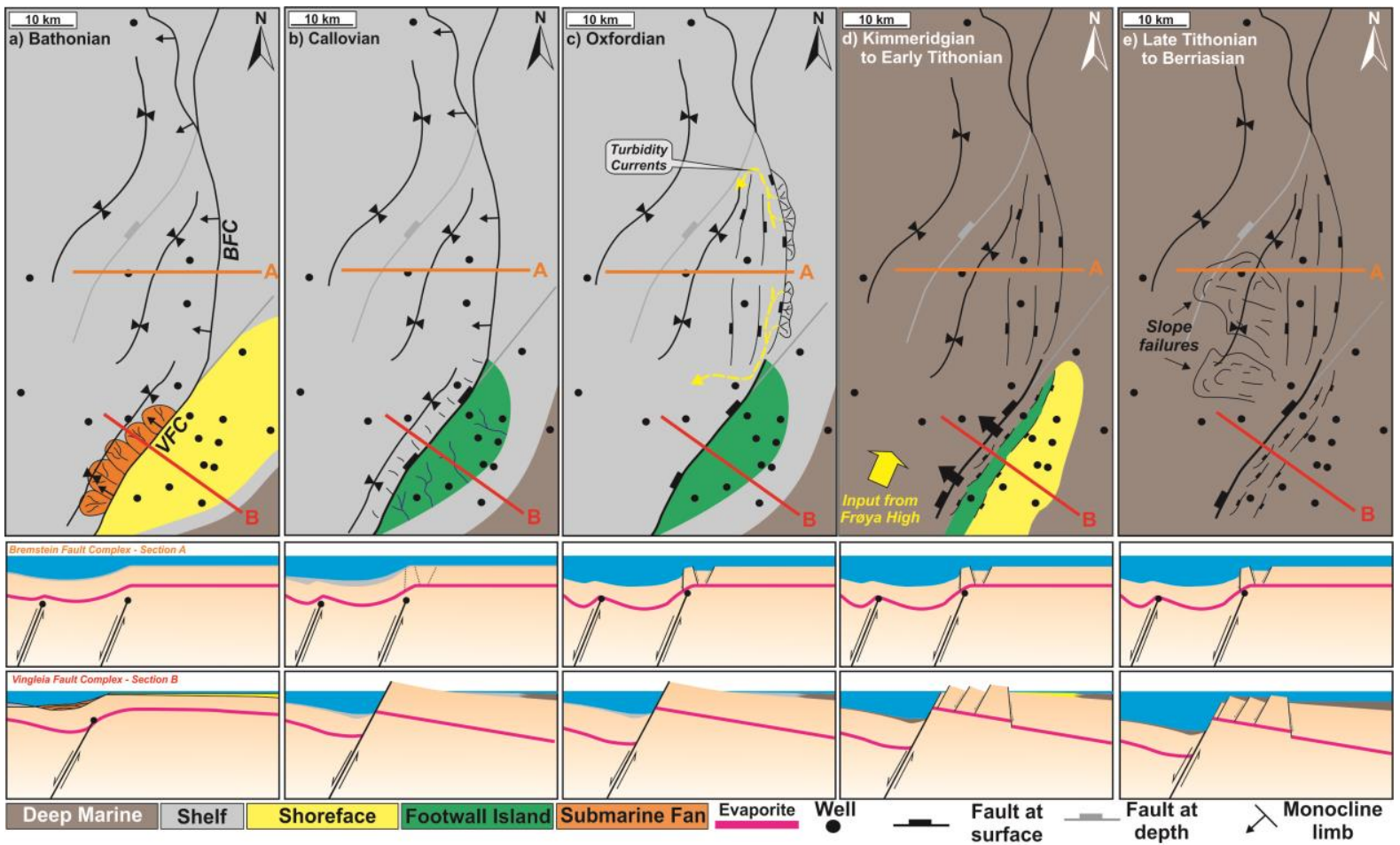

Figure 15: a) Monocline structure defines the eastern flank of the Halten Terrace with a shoreface environment present on the crest of the Vingleia and Bremstein Fault Complexes. In the Gimsan Basin, the Bathonian is characterised by a baselevel change which caused a change in facies from shoreface/shallow marine succession (Garn Formation) that was prevalent in the Bajocian/Early Bathonian to a deeper, shelfal setting in the Bathonian represented by the Melke Formation. Submarine fan systems developed along the SW flank of the basin. b) Shelfal settings dominated the Gimsan Basin and the Bremstein Fault Complex which continued to develop as a monocline system with extension partitioned across the evaporite. The Vingleia Fault Complex became a through-going fault system with footwall uplift and erosion along its crest. c) The Vingleia Fault Complex continued to be exposed through the Oxfordian although it was onlapped by shelfal siltstone and shale dominated successions. The Bremstein Fault Complex had developed as a series of horst and grabens with localised footwall erosion supplying sediment downdip although the complex topography ensured most sediment remained proximal to the fault complex. d) Renewed fault activity along the Vingleia Fault Complex promoted footwall collapse due to the detachment along the top of the evaporite unit. Localised footwall erosion occurred forming a shallow marine shoreface system in the hangingwall of one of the numerous crestal faults that developed. e) By the Late Tithonian, a regional sea level rise and cessation of faulting due to the onset of the post-rift period led to the draping of the entire area by deep-marine shales of the Spekk Formation. 


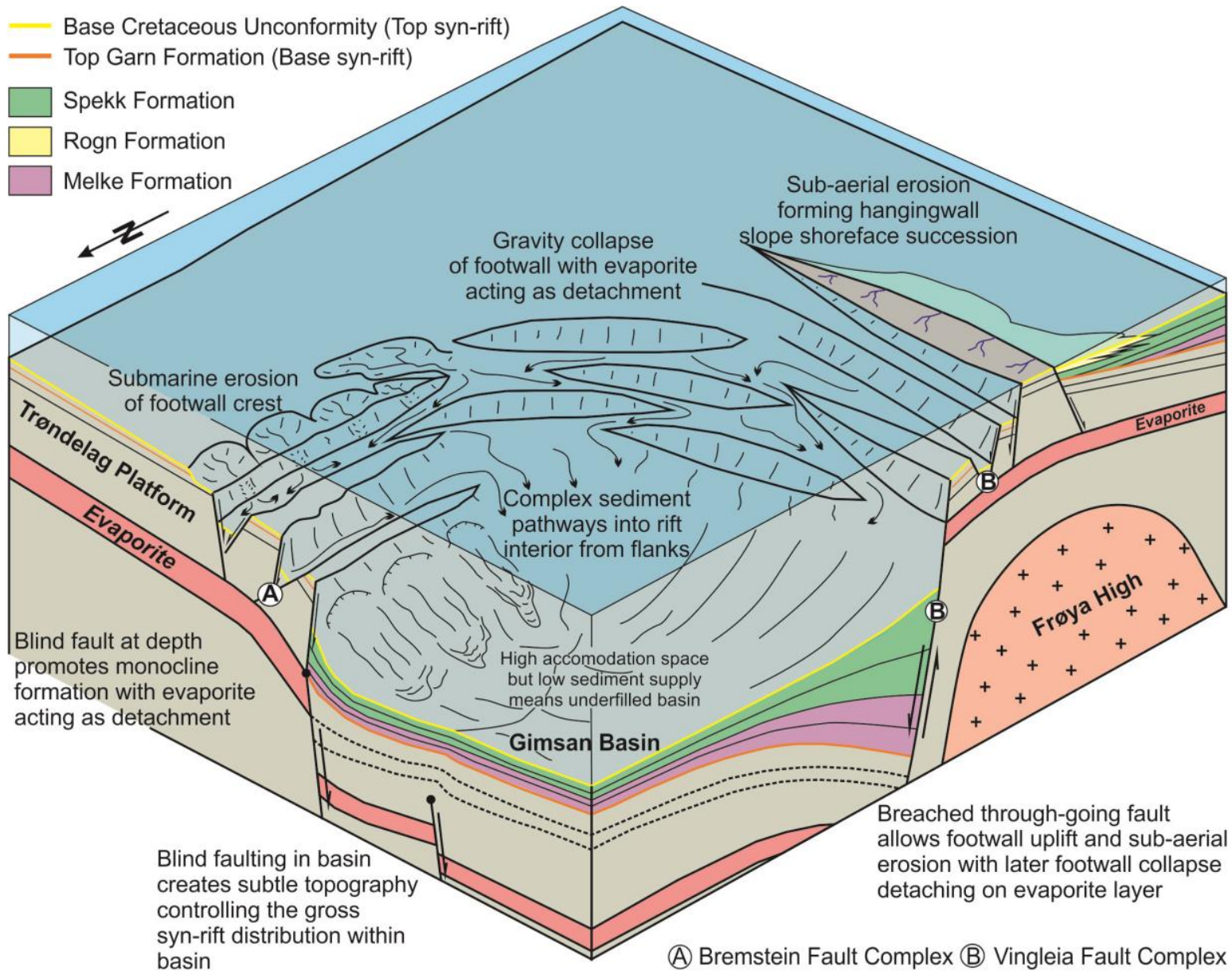

1151 Figure 16: Summary block diagram showing the influence an evaporite sequence can have upon the development of rift flank sedimentary systems. The variable topography along the rift flanks will promote local sediment supply along with small, localised accommodation space which means that syn-rift sediment accumulation will be localised along the rift flank with limited supply deeper into the rift basin. 


\begin{tabular}{|c|c|c|c|c|}
\hline Well & Structural Location & $\begin{array}{c}\text { Melke } \mathbf{F m} \\
\text { Thickness }(\boldsymbol{m})\end{array}$ & $\begin{array}{c}\text { Rogn } \mathbf{F m} \\
\text { Thickness }(\boldsymbol{m})\end{array}$ & $\begin{array}{c}\text { Spekk Fm } \\
\text { Thickness }(\boldsymbol{m})\end{array}$ \\
\hline $6407 / 2-1$ & Gimsan Basin & 31 & 0 & 66 \\
\hline $6407 / 4-1$ & Gimsan Basin & 117 & 0 & 62 \\
\hline $6407 / 5-1$ & Gimsan Basin & 86 & 0 & 247 \\
\hline $6407 / 6-1$ & Trondelag Platform & 13 & 0 & 8 \\
\hline $6407 / 6-4$ & BFC & 73 & 0 & 42 \\
\hline $6407 / 6-75$ & BFC & 0 & 44 & 77 \\
\hline $6407 / 7-8$ & Gimsan Basin & 145 & 0 & 67 \\
\hline $6407 / 8-1$ & Gimsan Basin & 344 & 0 & 212 \\
\hline $6407 / 8-2$ & VFC Footwall & 0 & 0 & 0 \\
\hline $6407 / 8-3$ & VFC Footwall & 0 & 0 & 27 \\
\hline $6407 / 8-4$ S & VFC Footwall & 0 & 0 & 0 \\
\hline $6407 / 9-3$ & VFC Footwall & 0 & 38 & 54 \\
\hline $6407 / 9-4$ & VFC Footwall & 0 & 2 & 21 \\
\hline $6407 / 9-5$ & VFC Footwall & 0 & 51 & 62 \\
\hline $6407 / 9-6$ & VFC Footwall & 0 & 17 & 32 \\
\hline $6407 / 9-8$ & VFC Footwall & 31 & 0 & 94 \\
\hline $6407 / 9-9$ & VFC Footwall & 0 & 0 & 9 \\
\hline
\end{tabular}

1159 Table 1: Summary table of wells used in the present study with Middle to Late 1160 Jurassic thicknesses shown (taken from Norwegian Petroleum Directorate database 1161 April 2012). 